\title{
Sire verification in multi-sire breeding systems
}

\author{
A Thesis Submitted to the \\ College of Graduate and Postdoctoral Studies \\ in Partial Fulfillment of the Requirements \\ for the Degree of Master of Science \\ in the Department of Animal and Poultry Science \\ University of Saskatchewan \\ Saskatoon, Saskatchewan
}

By Stacey Jo Domolewski

(C) Copyright Stacey Domolewski, 2017. All rights reserved 


\section{PERMISSION TO USE STATEMENT}

In presenting this thesis in partial fulfillment of the requirement for a Postgraduate degree from the University of Saskatchewan, I agree that the Libraries of this University may make it freely available for inspection. I further agree that permission for copying of this thesis in any manner, in whole or in part, for scholarly purposes may be granted by the professor or professors who supervised my thesis work or, in their absence, by the Head of the Department or the Dean of the College in which my thesis work was done. It is understood that any copying or publication or use of this thesis or parts thereof for financial gain shall not be allowed without my written permission. It is also understood that due recognition shall be given to me and to the University of Saskatchewan in any scholarly use which may be made of any material in my thesis.

Requests for permission to copy or to make use of material in this thesis in whole or in part should be addressed to:

Head of the Department of Animal and Poultry Science

University of Saskatchewan,

51 Campus Drive Saskatoon,

Saskatchewan S7N 5A8 


\begin{abstract}
An experiment was conducted to evaluate using DNA parentage testing on commercial cow-calf operations using multi-sire breeding groups to determine the associations between various traits of bulls and number of calves sired. Four commercial Saskatchewan ranches with 7 breeding groups collaborated in this study, where all potential sires and progeny were sampled to determine the sire of each calf. Expected vs observed calf data were analyzed using Chi-square analysis. In all but 2 of the 7 breeding groups, it was determined that each bull sired a different $(\mathrm{P}<0.01)$ number of calves. Age of sire was found to effect $(\mathrm{P}<0.01)$ bull prolificacy or number of calves sired. A bull prolificacy index (BPI) was developed to compare which bulls are siring more or less than expected number of progeny. All bulls were required to pass a breeding soundness exam (BSE) before breeding season, therefore weak correlations were found between scrotal circumference $\left(\mathrm{R}^{2}=0.04\right)$ or percent normal sperm $\left(\mathrm{R}^{2}=0.13\right)$ and BPI values. No sire match ranged from $2-7 \%$ of calves tested. Testing only calves born in the $3^{\text {rd }}$ week of calving, indicated that bulls could be assigned accurately to high or low prolificacy categories, but bulls with the fewest number of calves sired could not be detected.

Economic models were developed to evaluate the value of adopting parentage testing on farm using a cost benefit analysis. The model showed bulls that sired more calves had a lower cost per calf sired. Based on the model, if bulls were siring $<25$ calves it would be more economical to use AI in the breeding program. The model also determined that if one bull was causing increased dystocia rates in a herd, testing calves from difficult births to cull responsible bulls did provide an economic return on investment to the operation. There is potential to increase overall bull prolificacy in a herd and increase other economically important traits by using DNA parentage to aid in sire selection.
\end{abstract}




\section{ACKNOWLEDGEMENTS}

I would like to thank Dr. Bart Larnder for all of his support and guidance throughout the course of this study. Thank you for your encouragement and for helping me to navigate any difficulties that arose throughout this trial. Thank you to my committee members Dr. John Cambpell and Dr. Fiona Buchanan and the graduate committee chair Dr. Tim Mutswanga for their continued assistance with my research project and thesis writing. Thank you also to Dr. Steve Hendrick, and Kathy Larson for the time you took to assist me in the statistical and economic analysis of this project, it is really appreciated.

To the Western Beef Development Centre staff, especially Leah Pearce and Crystal Savenkoff for your cooperation in data collection and for always supplying me with the production records I needed. To the collaborating ranches, thank you for your willingness to share your farm records and help with data collections. To the BCRC staff, thank you so much for your advice and understanding throughout this process.

To my family Grandma and Grandpa, Momma C, Dad and Becky, thank you for all of your support and encouragement along the way. Thank you for always helping me out whether it was feeding my cows, making sure my car was always running, or just being at the other end of the phone. A special thank you to Grandma Ruth for teaching me from a young age that I was capable of everything I put my mind to, and for reminding me of that as I got older. Thank you to all of my friends who have supported me through this journey, especially the El Rancho girls for all that they have done to help make this research project a success. To Lon and Sue, thank you for always taking the time to be interested in my work and encouraging me to pursue this degree. To the many other extended family, family friends, and neighbours who have helped me in any small way throughout this project. I am so blessed to have such a great support system. 


\section{TABLE OF CONTENTS}

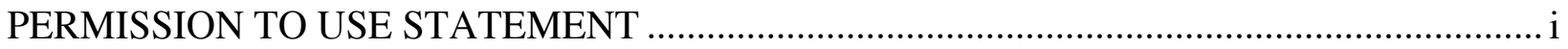

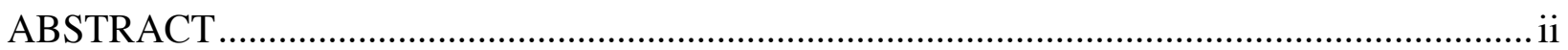

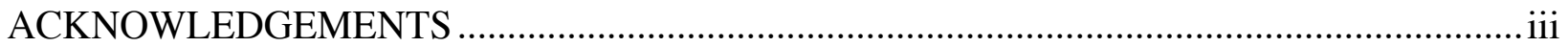

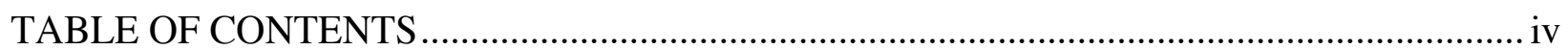

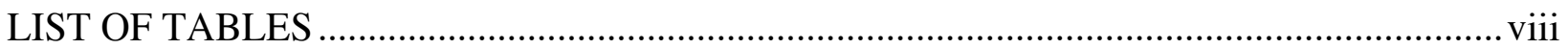

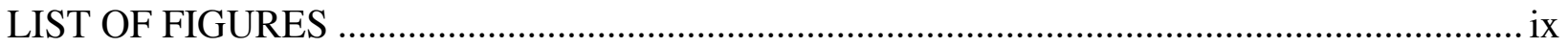

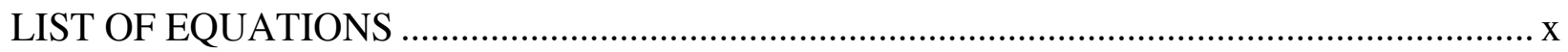

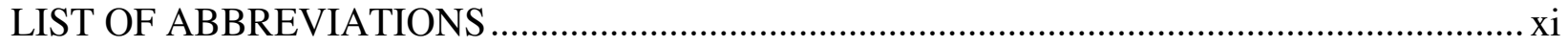

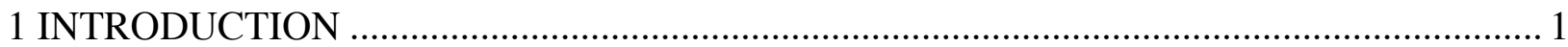

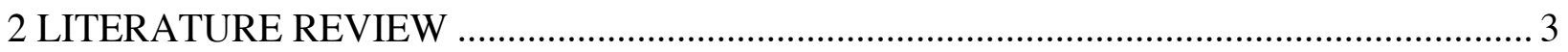

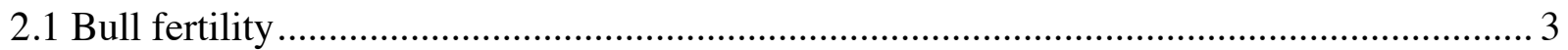

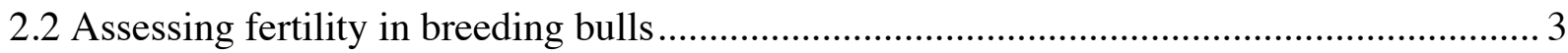

2.2.1 Breeding soundness evaluation (BSE) .................................................................... 4

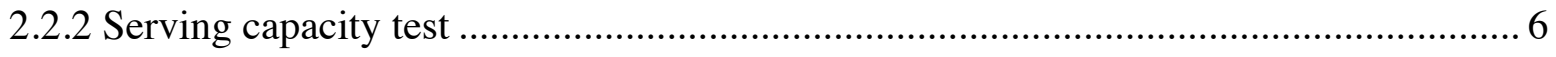

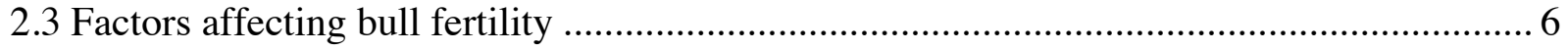

2.3.1 Sire age

2.3.2 Physical soundness examination ............................................................................ 7

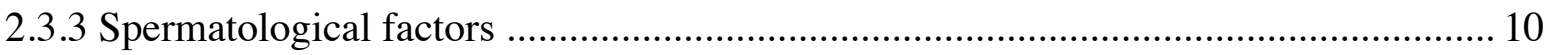

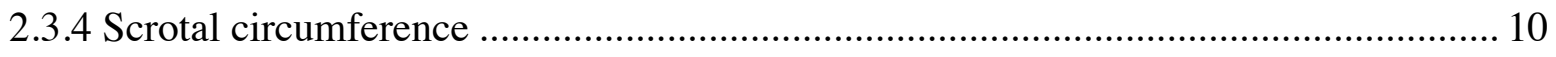

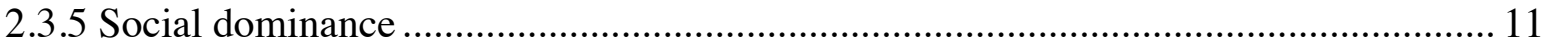


2.3.6 Mating behaviour and libido .......................................................................... 12

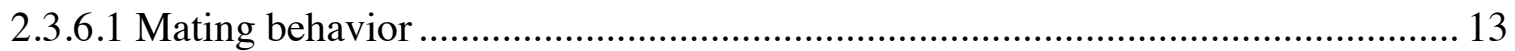

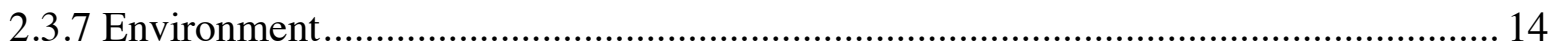

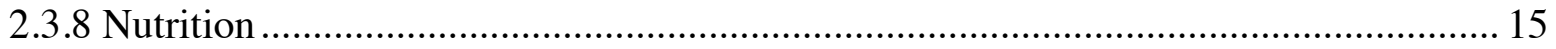

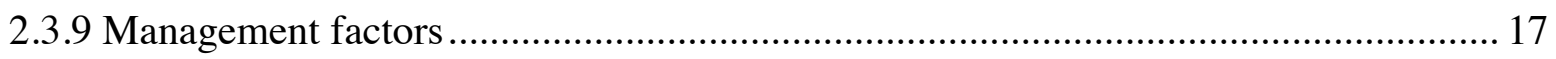

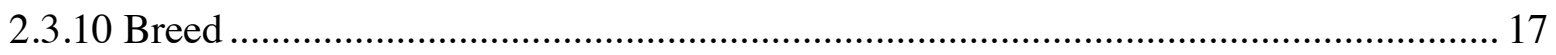

2.3.11 Interaction between the cow and bull for reproductive success ............................. 18

2.3.12 Use of multi-sire breeding pastures in western Canada ...................................... 19

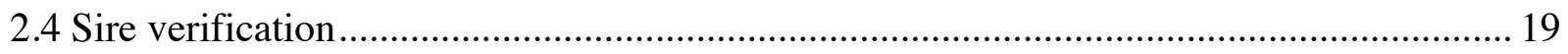

2.4.1 Sire verification in the purebred industry ....................................................... 19

2.4.2 Sire verification in multi-sire breeding pastures .............................................. 20

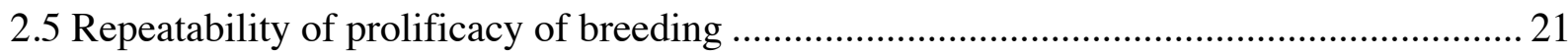

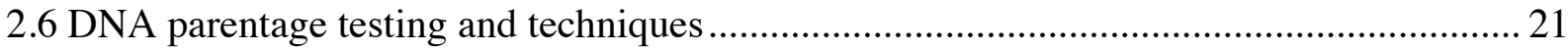

2.6.1 Single nucleotide polymorphism ............................................................... 22

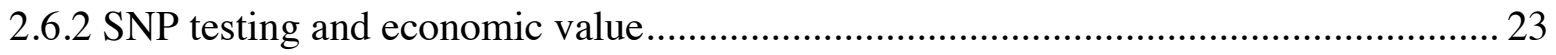

2.7 Alternatives to full DNA parentage testing programs ............................................... 23

2.7.1 Identifying sires causing dystocia .............................................................. 24

2.7.2 DNA testing a portion of the calf crop.......................................................... 24

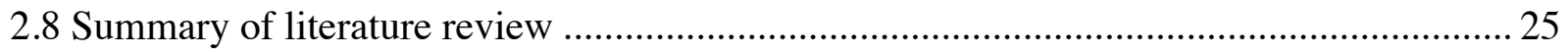

3.0 EVALUTION OF BULL PROLIFICACY IN MULT-SIRE BREEDING SYSTEMS ......... 26

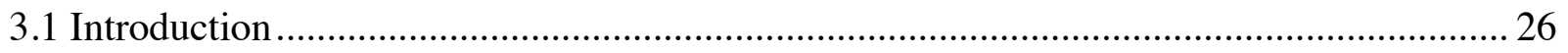

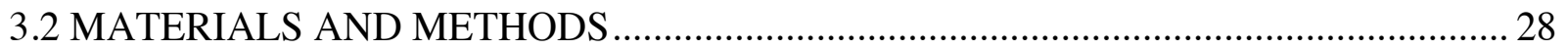

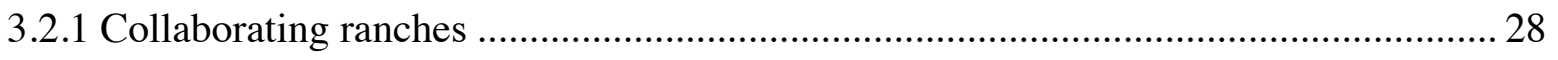




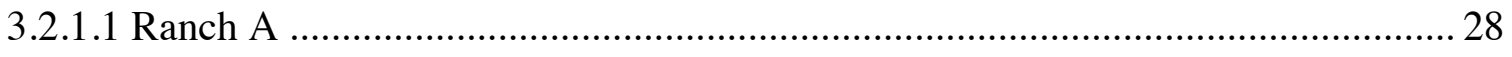

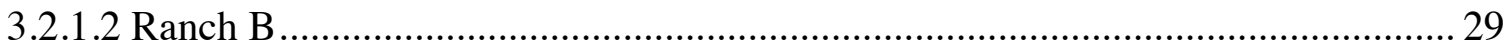

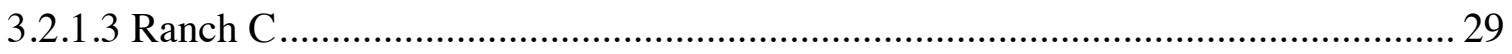

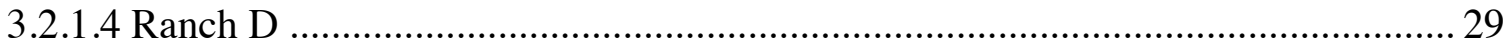

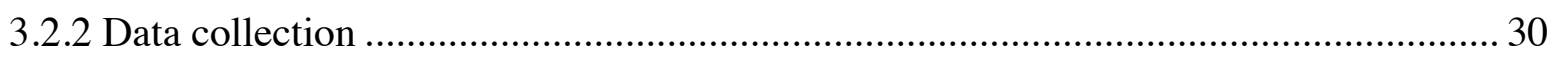

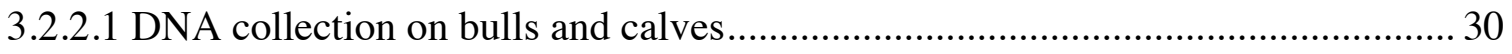

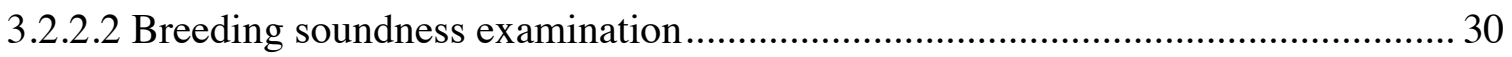

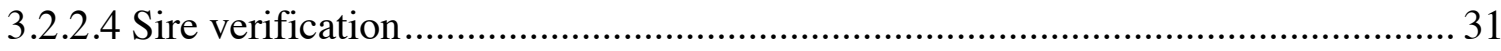

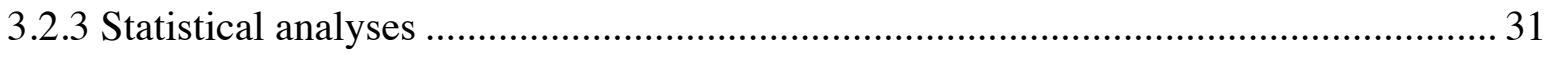

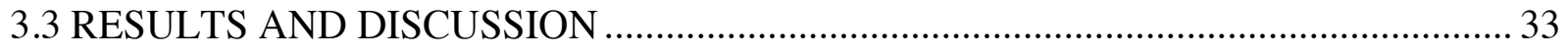

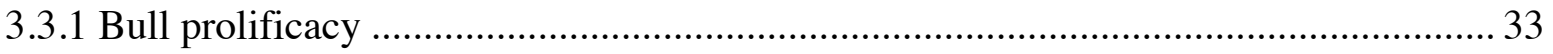

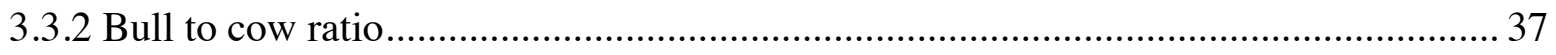

3.3.3 Sire age

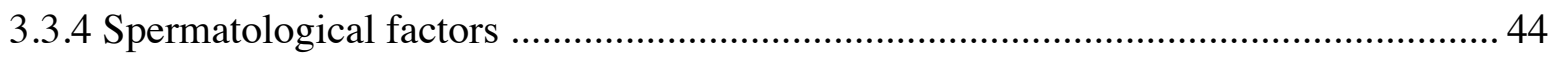

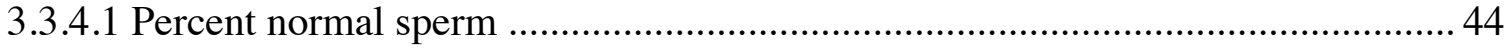

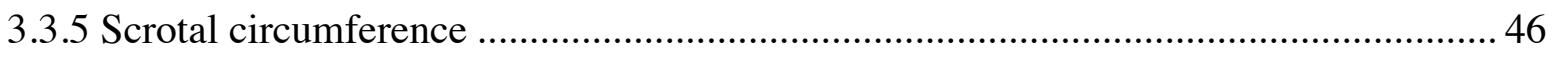

3.3.6 Number of bulls per pasture .................................................................................. 48

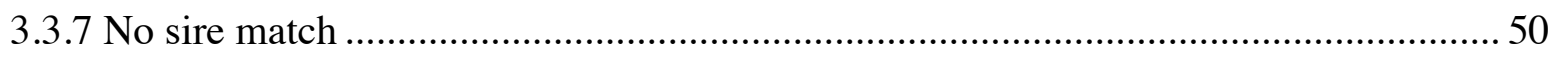

3.3.8 Alternative sampling methods ……………………............................................. 51

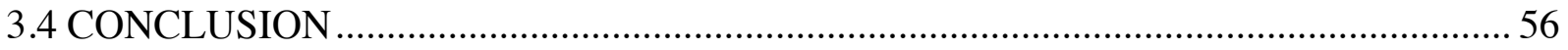

4.0 ECONOMICS OF DNA PATERNITY TESTING AS A METHOD TO DETERMINE

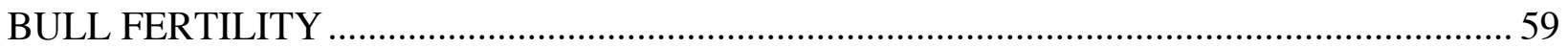

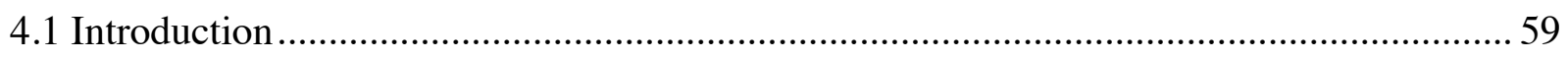




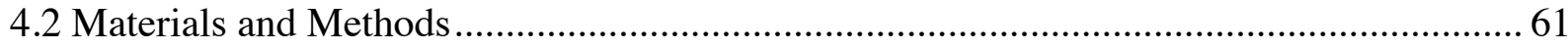

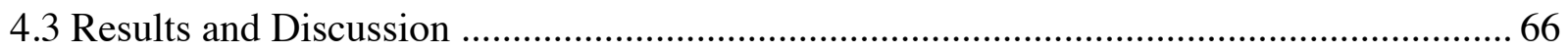

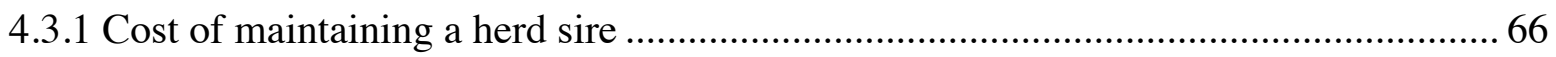

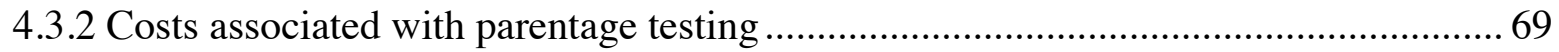

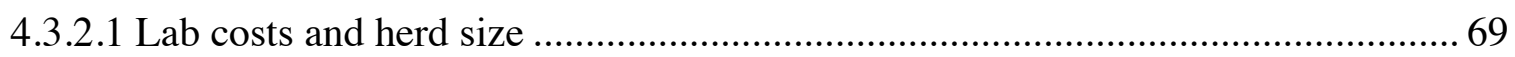

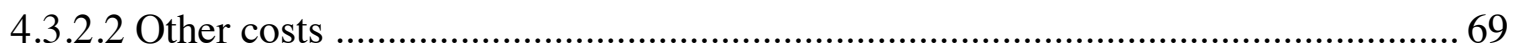

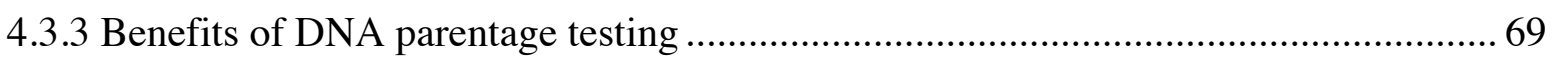

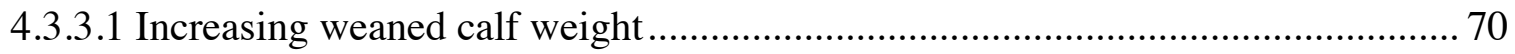

4.3.3.2 Removal of non-prolific sires ....................................................................... 71

4.3.3.3 Using parentage test results to reduce dystocia ………………………............ 73

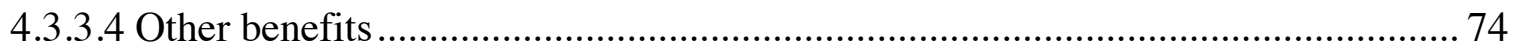

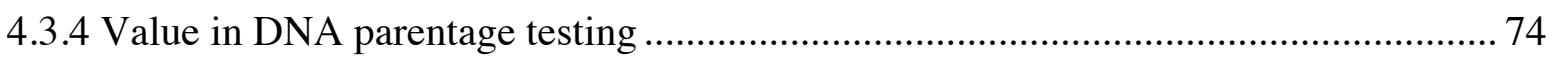

4.4 Turnaround time from sampling to DNA parentage results ............................................ 76

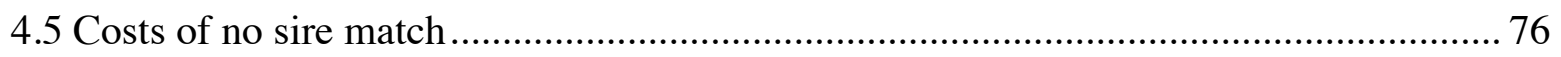

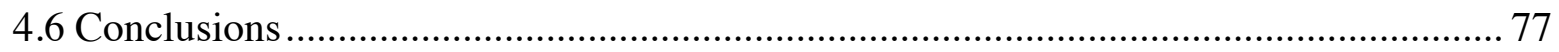

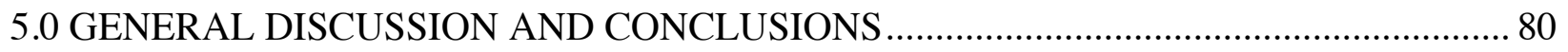

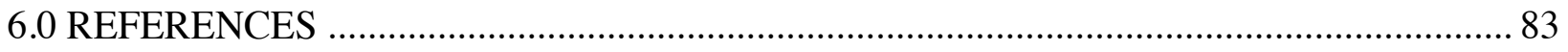

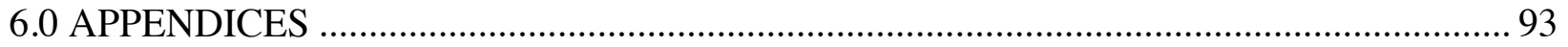




\section{LIST OF TABLES}

Table 2.1 Minimum requirements for scrotal circumference for several bull breeds--------------- 11

Table 3.1 Descriptive statistics on number of calves sired per bull in each breeding group ----- 33

Table 3.2 Results of Chi square analysis comparing observed vs expected progeny per bull in

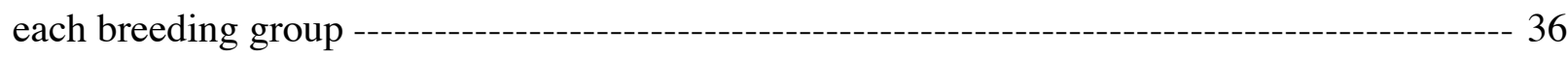

Table 3.3 Number of sires and bull to cow ratio for each breeding group and the corresponding

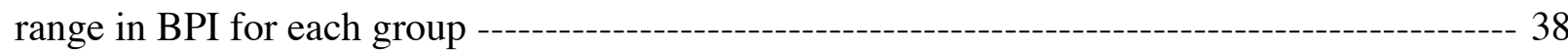

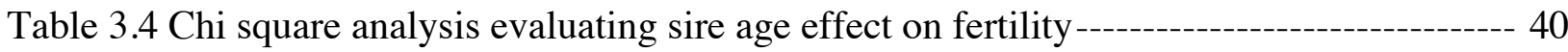

Table 3.5 Descriptive statistics for percent normal sperm per breeding group compared to

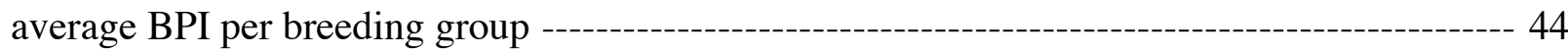

Table 3.6 Comparison of BPI for calves born in first $21 \mathrm{~d}$, week 3, and total calves born from Ranch A ----- 53

Table 3.7 comparing the agreement between the number of bulls classified as high prolificacy (BPI $>0.50$ ) or low prolificacy (BPI $<0.05$ ) of calves born in just the first 21 days VS total calves born on Ranch A

Table 3.8 comparing the agreement between the number of bulls classified as high prolificacy (BPI $>0.50$ ) or low prolificacy (BPI $<0.05$ ) of calves born in just week 3 VS total calves born

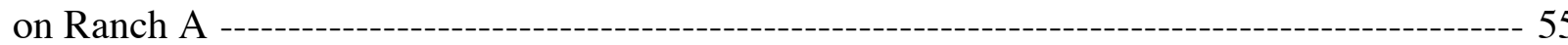

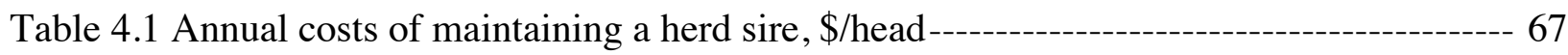

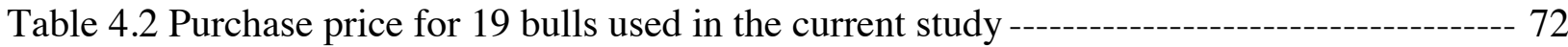

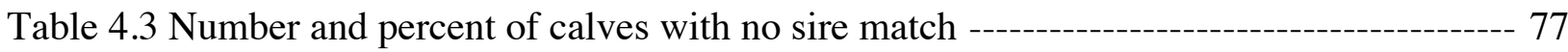




\section{LIST OF FIGURES}

Figure 3.1 Comparison of BPI for yearling, 2-yr-old, and mature bulls ............................... 42

Figure 3.2 Comparison of BPI and SC values of all bulls showing weak correlation $\left(\mathrm{R}^{2}=0.04\right)$

between SC and BPI

Figure 3.3 Coefficient of determination between number of bulls per breeding group and the standard deviation (SD) of calculated BPI for each group ................................................. 49

Figure 3.4 Percent of total 2015-born calves born each week at Ranch A ............................... 52 


\section{LIST OF EQUATIONS}

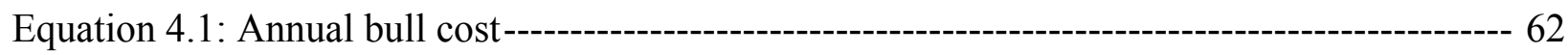

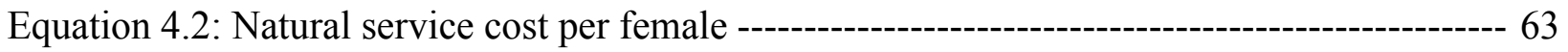

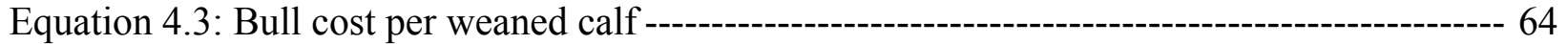

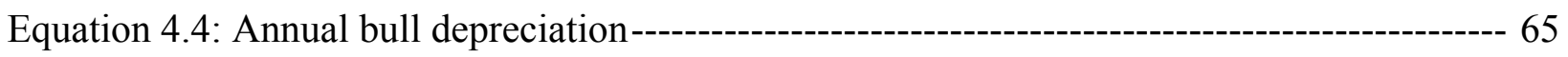




\section{LIST OF ABBREVIATIONS}

ADG Average daily gain

BCS Body condition score

BPI Bull prolificacy index

BW Body weight

BSE Breeding soundness evaluation

CFV Campylobacter fetus spp. Venerealis

CP Crude protein

DF Degrees of freedom

DM Dry matter

DMI Dry matter intake

DNA Deoxyribonucleic acid

LH Luteinizing hormone

PCR Polymerase chain reaction

SD Standard deviation

SC Scrotal circumference

SCT Serving capacity test

SNP Single nucleotide polymorphism

TDN Total Digestible nutrients

UK United Kingdom

WBDC Western Beef Development Centre

WCABP Western Canadian Association of Bovine Practitioners

WW Weaning weight 


\section{INTRODUCTION}

In commercial cow-calf operations there are two main factors that determine income, the number of animals that are available to sell and the value of each animal sold (Garrick and Golden 2009). When relating this back to the bull it can be assumed that the value of the bull lies in the number of calves that are sired and the value of the traits that he passes on to those calves (high weaning weights (WW), feed efficiency, etc. Garrick and Golden 2009). This suggests that a bull can be of very high quality but low economic value if they are only siring a few calves per year. Bulls are selected for a variety of traits depending on producer preference (high average daily gain (ADG), high weaning weights, low birth body weights (BW), etc.), but these traits have nothing to do with fertility, and may even have a negative correlation (Ologon et al. 1981). Deoxyribonucleic acid (DNA) sire verification provides an opportunity to calculate the economic return on investment for a bull regardless of his assumed value due to phenotypic traits.

Even though the number of calves that each bull sires is a large part of the income from the bull, producers often are not aware of the number of calves sired by each bull in multi-sire breeding pastures. Unknown parentage in multi-sire breeding groups is most likely because there are very few ways to accurately determine bull fertility both pre- and post-breeding. Using DNA sire verification is the only currently available technology that can be used to determine the number of calves sired by each bull in a multi-sire breeding pasture.

In most economic analysis of multi-sire breeding pastures, it is generally assumed that every bull is siring an equal number of progeny (Lunstra, 1985). A recent American study showed that bulls in multi-sire pastures sired anywhere from 0 to greater than $50 \%$ of the annual 
calf crop (Van Eenennaam et al. 2007). If this is the case, a percentage of sires used in multi-sire breeding pastures are actually costing a producer money (Van Eenennaam et al. 2007). A case could be made for culling these non-prolific sires if there is enough evidence to suggest that siring a low number of progeny is repeatable year after year.

Past studies have shown that sire prolificacy is a moderately repeatable trait $\mathrm{r}=0.43$ to 0.69 (Holroyd et al., 2002) suggesting that sire verification can be relied on to make culling decisions about non-prolific sires. That being said, there is currently no multiyear western Canadian studies that have been conducted evaluating the importance and economic value of sire verification in multi-sire breeding programs.

The objectives of this review are to 1) discuss factors that are known to effect bull fertility and libido; 2) review DNA parentage testing and techniques and determine the value of using the technology when making bull culling decisions; 3) provide an overview of multi-sire breeding programs in western Canada and the value to producers. 


\section{LITERATURE REVIEW}

\subsection{Bull fertility}

Bull fertility is a major factor affecting the economics of any cow calf operation. Since bulls provide half of the genetics for a cow-calf operation, and the profitability of an operation depends on number of calves sold and the weight of those calves (Garrick and Golden 2009), the bull plays a major role in profitability of a cow-calf operation. To begin with, beef cattle only have a calving rate around 50-60\% for each service (Rowlands and Weir 1984). It is believed that this is mainly due to low embryo survival rates (Rowlands and Weir 1984). Low embryo survival rates cannot be changed by bull management but this does underscore the importance of high fertility in bulls to ensure maximum pregnancy rates.

It could be argued that the most important trait to select for in a sire is fertility. Other traits such as ADG, feed efficiency, WW, and marbling percentage are often selected for and are of economic value, but are of no value unless the bull is able to sire calves and pass those traits on to its offspring (Van Eenennaam et al. 2014) Many factors are required for a bull to be able to establish pregnancy in a fertile cow. The bull must first reach puberty, have adequate scrotal circumference, produce viable, fertile sperm, be physically sound, and be able to mount the cow (Barth 2013; Chenoweth 1997). In addition, libido and social dominance also play a role in bull fertility (Blockey 1979b). All of these components are equally important for fertility, but not all of them are easy to assess or measure in a commercial industry setting.

\subsection{Assessing fertility in breeding bulls}

Although no large scale, western Canadian studies have been performed to determine prolificacy rates in individual bulls, it is known that not all bulls are able to successfully establish 
pregnancy in females (Barth 2013; Chenoweth 1997). When looking at 2990 breeding soundness evaluations of bulls, Waldner et al. (2010) found that $91.3 \%$ of bulls evaluated were found to be satisfactory. Bulls with reduced fertility have the ability to reduce pregnancy rates in a herd and delay conception (Lunstra and Coulter 1997). Delaying the establishment, or failing to establish pregnancy in cattle can result in loss of income for the producer (Houghton et al. 1990).

\subsubsection{Breeding soundness evaluation (BSE)}

In a survey of Saskatchewan beef producers, it was found that $68.9 \%$ of producers had a breeding soundness evaluation (BSE) performed on at least one bull in the previous breeding season (Jelinski et al. 2015). It is strongly recommended that producers perform the BSE near the beginning of the breeding season (Bagley and Burrell 1997). The purpose of a routine BSE is to determine the breeding potential of a bull, based on several areas of examination. Wiltbank and Parish (1986) showed that by utilizing the results of BSE tests and screening their bull herd accordingly, producers could increase herd fertility by up to 5 percent. Since no one factor accurately determines fertility, many variables or measures are taken into account to derive an overall classification of unsatisfactory or satisfactory (Chenoweth et al. 1992). All factors evaluated determine if the bull has the physical and physiological potential to establish pregnancy in normal, fertile females (Kastelic and Thundathil 2008). Although the BSE is shown to be effective, it doesn't assess the libido and actual mating ability of the bull (Farin et al. 1989). Even though there is a strong correlation between BSE scores and number of pregnancies obtained, this does not guarantee $100 \%$ pregnancy rates as it has been shown that the maximum contribution of semen to pregnancy rates is about 60 percent (Linford et al. 1976).

The routine BSE includes a physical examination of feet, legs, eyes, and sheath, a body 
condition score (BCS), scrotal palpation to evaluate testes, epididymis, spermatic cords, scrotal skin, measurement of scrotal circumference, and a semen evaluation (Chenoweth et al. 1992).

Bulls must meet minimum requirements for each section of a BSE to pass and are then classified accordingly (Barth, 2013). Bulls that do not meet requirements can be classified as either unsatisfactory or they can defer classification suggesting that the producer have the bull retested later in life (Barth, 2013). Bulls that are classified as "defer classification" are most frequently young bulls as scores are likely to increase from unsatisfactory to satisfactory in a second examination (Elmore et al. 1975).

Because a BSE is only evaluating the specific time period when the test is being conducted, it does a poor job of evaluating future breeding potential (Kennedy et al. 2002;

Kastelic and Thundathil 2008). This is more of a concern in young bulls, as Ellis et al. (2005) reported that yearling bulls that were used for breeding not only lost body weight (BW) throughout the breeding season, but also experienced a reduction in scrotal circumference (SC), or a reduction in $\mathrm{SC}$ growth, compared to a control group of bulls that did not breed. There was also a higher incidence of injury among yearling bulls that were used for breeding, and decreased numbers of bulls in the breeding group were able to pass the BSE post breeding (Ellis et al. 2005). Even accounting for injuries and lower numbers of bulls passing the second BSE, the bulls were still able to achieve relatively high pregnancy rates (91-96\%; Ellis et al. 2005). Unfortunately, the study didn't follow the bulls in the next breeding season to determine any carry over effects on subsequent breeding performance. 


\subsubsection{Serving capacity test}

The serving capacity test (SCT) was developed as a way to evaluate bull libido and sexual efficiency (Blockey 1981). The original method of measuring serving capacity was to observe bulls in a pasture with estrus heifers and observe the number of services achieved by each bull during an observation period (Blockey 1976). Because the original method was extremely time consuming and impractical in a commercial setting a new method was developed that simulated pasture mating situations (Blockey 1981). Blockey (1981) exposed bulls to an immobilized estrus female for $1 \mathrm{~h}$ and recorded the number of services that were correlated with the number of services experienced over a $19 \mathrm{~d}$ observation period and therefore with bull prolificacy. Bulls with higher scores in a SCT also have higher number of services when exposed to females in pasture mating situation (Blockey 1976; Blockey 1981)

\subsection{Factors affecting bull fertility}

Although significant work has been conducted on bull fertility and the effects of environment, spermatological, libido, breed, and age factors on fertility (Wiltbank and Parrish 1986; Barth 1989; Zamboni 1992; Barth and Waldner 1994; Evans et al. 1995; Kastelic and Thundathil 2008), very little work has been conducted on how these factors affect a bulls ability to sire calves in multi-sire breeding pastures where bulls are breeding cows in large groups and dominance and social hierarchies play a role.

\subsubsection{Sire age}

Semen quality and quantity are known to be affected by bull age (Stalhammar et al. 
1989), therefore it would be expected that age would also play a role in fertility and number of offspring sired by a bull. Van Eenennaam et al. (2007) found that in pasture breeding situations where calves were DNA tested for sire verification, of the 10 bulls in the study that did not produce offspring, 9 were yearling bulls. Early work by Carpenter et al. (1992) also reported that bulls 14 to16 mo of age showed poor performance in a SCT, and suggested that testing bulls before 20 mo of age was not an accurate way to make culling decisions.

Previous studies evaluating bull performance in multi-sire pastures have not used older mature bulls (greater than 6 years of age; Holroyd et al. 2002; Van Eenennaam et al. 2007). It can be expected that as bulls grow older, eventually they will reach a plateau where sperm quality, and libido no longer increase (Foote et al. 1976) resulting in a decreasing number of calves sired. Ruttle et al. (1983) suggested that sperm quality can decline in beef sires after the animal is 6 yr of age or older.

\subsubsection{Physical soundness examination}

A bull must be physically sound and have good feet and leg structure to be able to withstand the demands put on them due to increased mounting activity during the breeding season (Chenoweth et al. 1992). Physical injury, or fatigue caused by inadequate feet and leg conformation even lead to situations where bulls mount cows but do not actually service them (Coulter and Kozub 1989). Physical soundness issues may arise during the breeding season due to injury or disease, they may also be the result of fatigue due to poor feet and leg conformation especially when breeding in muddy pens where slipping during mounting is more likely to occur (Baggott and Russell 1981). Bulls fighting may also result in injury and lameness (Anderson and Rogers 2001). Ellis et al. (2005) observed an extremely high incidence of physical injury of bulls 
in multi-sire breeding pastures $(34 \%)$ and noted that there was a correlation $(\mathrm{P}<0.05)$ between sire lines and incidences of physical injury.

Physical soundness plays a key role in mating behavior as it determines if the animal is healthy, structurally sound, and in good enough physical condition to endure the high demands during the breeding season (Chenoweth et al. 1992). During a BSE both internal and external examinations are performed. A trans-rectal examination is performed to evaluate the secondary sex organs including the urethra, prostrate, seminal vesicles, ampullae, and vas deferens (Kreplin 2007).

An external examination is used to evaluate the penis, prepuce, scrotum, and testicles (Kennedy et al 2002). The scrotum is palpated to evaluate the testicles and epididymis, other conditions such as cryptorchidism, which results when the testis fail to descend normally into the scrotum are also tested through the scrotal palpation or rectal examination. Cryptorchidism is not commonly seen in bulls (Saunders and Ladds 1978; Carson and Wenzel 1997) but does result in a failure to pass the BSE as well as reduced semen quality and quantity (St. Jean et al. 1992).

A general health exam is also performed focusing on feet and legs to ensure the bull is capable of walking long distances and that the back legs and hind muscles are able to support their weight when they mount a cow (Kreplin 1992). Barth and Waldner (2002) reported that bulls that were lame due to feet or leg problems, were less likely to have acceptable semen quality, with only $25 \%$ of lame bulls having high enough quality semen to pass the breeding soundness evaluation. Lameness and physical injury is known to cause stress in dairy cows to the extent that it reduces pregnancy rates (Collick et al. 1989). No work has been performed to assess why breeding bulls who are lame sire less calves; but looking at the work of Collick et al. (1989) it is reasonable to assume that stress plays a role. Stress in the bull is associated with an 
increase in corticosteroids which will cause a decrease in luteinizing hormone (LH). Luteinizing hormone is responsible for stimulating the Leydig cells to produce testosterone (Evans et al. 1996) meaning that lower LH levels lead to a decrease in testosterone and therefore semen production (Welsh and Johnson 1981). Since quantity and quality of semen produced are measured in the BSE (Chenoweth et al. 1992) and are affected by lameness (Barth and Waldner 2002), it is critical that a physical examination be included in the BSE to eliminate bulls whose physical condition may inhibit future semen production and ultimately number of calves sired (Collick et al. 1989).

Tessitore et al. (2011) showed that feedlot cattle that were not lame grew at a rate of 2.34 $\mathrm{kg} / \mathrm{d}$ vs. lame cattle that grew at a rate of $0.8 \mathrm{~kg} / \mathrm{d}$, presumably due to a lower dry matter intake (DMI). Although no work has been conducted assessing DMI of lame bulls it can be extrapolated from data on feedlot steers that this reduced intake would also apply to bulls, especially when in pasture conditions, or in group feeding situations where bulls must search or compete for food. It can then be hypothesized that some of the decreased sperm quality may be associated with low feed intake (Meacham et al. 1963; VanDemark et al. 1964; Rekwot et al. 1988; Martin et al. 1994). Bulls with low DMI are known to have reduced scrotal circumferences, reduced semen production, reduced number of sperm per ejaculate, and decreased sperm motility (Meacham et al. 1963; VanDemark et al. 1964; Rekwot et al. 1988; Martin et al. 1994).

In their study, Barth and Waldner (2002) did not investigate the different factors of semen quality that were influenced by lameness, only if the bull was able to successfully/unsuccessfully pass a breeding soundness evaluation. A more in-depth look at semen quality problems associated with lameness would be beneficial in assessing why lameness results in decreased ability to pass a breeding soundness evaluation. 


\subsubsection{Spermatological factors}

Selecting bulls for improved semen quality has been shown to increase pregnancy rates (Wiltbank and Parish 1986). Semen is primarily evaluated for morphology and motility, and the bull must have greater than a $60 \%$ motility score to pass. Previous research has shown that motility scores $<60 \%$, tend to be detrimental to pregnancy rates, yet scores $>60 \%$ have not been shown to increase pregnancy rates (Barth, 2013).

Sperm morphology is also evaluated in a BSE exam, and it is well documented that morphological defects in sperm can result in reduced rates of fertilization and embryonic development (Wiltbank and Parrish 1986; Barth 1989; Zamboni 1992). Both factors of sperm motility and morphology are shown to be correlated with a decrease in fertility (Barth, 1989) and possibly with an increased ability to sire more calves.

\subsubsection{Scrotal circumference}

Scrotal circumference (SC) is measured by using a specialized tape measure that standardizes the amount of pressure applied to the widest part of the scrotum (Coulter and Foote 1979). Scrotal circumference is measured as a way of estimating scrotal weight (Hahn et al. 1969). Testes weight is evaluated as there is a strong correlation between testes weight, sperm concentration, and number of spermatozoa per ejaculate (Hahn et al. 1969). The correlation between SC and sperm production is only efficient with younger bulls as after 5 to $6 \mathrm{yr}$ of age changes in testicular weight due to fat deposition mask the correlation between SC and spermatozoa produced per ejaculate (Hahn et al. 1969). Values for acceptable SC differ by breed 
and age, but minimum values must be reached to pass (Table 2.1).

Table 2.1 Minimum requirements for scrotal circumference for several bull breeds

\begin{tabular}{ccccc}
\hline Age (mo.) & $\begin{array}{c}\text { Simmental, } \\
\text { Angus, Charolais }\end{array}$ & $\begin{array}{c}\text { Hereford, } \\
\text { Shorthorn }\end{array}$ & $\begin{array}{c}\text { Speckled Park, } \\
\text { Saler }\end{array}$ & Limousin \\
\hline 12 & 32 & 31 & 30 & 29 \\
13 & 33 & 32 & 31 & 30 \\
14 & 34 & 33 & 32 & 31 \\
15 & 34.5 & 33.5 & 32.5 & 31.5 \\
16 to 20 & 35 & 34 & 33 & 32 \\
21 to 30 & 35 & 35 & 34 & 33 \\
\hline
\end{tabular}

Adapted from Barth (2013).

Scrotal circumference has been previously shown to correlate with both sperm quality and quantity (Waldner et al. 2010; Garmym et al. 2011). Waldner et al. 2010 found that bulls with a SC in the bottom $10^{\text {th }}$ percentile had percent normal sperm $3.4 \%-6.3 \%$ lower than bulls with SC that were larger. In their study researchers also found that bulls with lower SC had a decreased number of percent live sperm when compared to bulls with SC that were larger.

\subsubsection{Social dominance}

Social dominance also plays a key role in bull fertility as the older, larger bulls that have been on a cattle operation for a longer period of time also tend to be the most dominant bulls in a multi-sire group (Blockey 1979b). Social dominance order has been shown to correlate with sexual activity (Blockey 1979b) and also an increase in number of calves sired (Dzuik 1996). Problems can arise if the older, or more dominant bull becomes injured or has poor semen quality, as just the presence of a dominant bull may prevent other bulls from breeding (Lopez et al. 1999). 
The amount of time that bulls have been in the same pasture and their ability to actually establish a social order has an effect on bull performance (Blockey 1979a). If bulls have already established a social dominance order they are more likely to display dominance towards other bulls in a breeding situation through threatening behaviour whereas bulls that were not in the same pasture originally spent more time in physical combat with other bulls (Blockey 1979a; Price and Wallach 1991). This suggests that bulls would spend more time establishing dominance through physical combat instead of breeding cows when they were not previously exposed to other bulls in the pasture.

\subsubsection{Mating behaviour and libido}

Libido is a key characteristic to bull fertility and the ability for a bull to breed cows. Libido becomes even more important in a multi-sire breeding pasture where bulls are in competition and dominance hierarchy is present (Chenoweth et al. 1979). Libido is often not measured because there is currently no single, commercially viable technique.

In some research settings, libido is measured using a servicing capacity score and is determined by exposing a male to a group of restrained females and measuring time to first mount, number of mounts and number of services in a given time period (Chenoweth et al. 1979). The SCT can be tested for a group of bulls or individually (Chenoweth et al. 1979). Group interactions, social hierarchies and competition between bulls for estrous females all play a role in libido. Price and Wallach (1991), showed that during a libido test, increasing the bull to female ratio by increasing the number of bulls caused increased aggression between bulls and by association reduced overall sexual activity. Although the exact reason for reduced sexual activity cannot be determined it was assumed that increased aggression resulted from increased time 
spent fighting other bulls as opposed to servicing the females (Price and Wallach 1991).

Libido is known to impact the ability of bulls to establish pregnancy in fertile cows (Coulter and Kozub 1989). Bulls with high scores in a SCT have been shown to have higher conception rates than bulls with low serving capacity scores in pasture breeding situations (Crichton and Lishman 1988). This suggests that serving capacity scores are good indicators to determine if a bull will successfully go out and breed cows. Coulter and Kozub (1989) also showed that number of mounts (not actual services) when exposed to a heifer had a negative influence on bull fertility. Although these methods that allow producers to assess libido are correlated to number of calves sired by a bull, they are impractical to use under commercial farm conditions.

Since libido and/or serving capacity tests cannot easily be conducted in a commercial setting, bulls are not usually tested. Thus, producers may subjectively, informally, evaluate libido based on personal observations. Parentage verification therefore can serve as a method to indirectly evaluate bull libido (Coulter and Kozub 1989).

Other methods of assessing libido such as a blood tests for testosterone and LH levels that could be easily measured on farm have been evaluated, (Chenoweth et al. 1979), but researchers have yet to find a trait that is highly correlated with libido to make the test effective.

\subsubsection{Mating behavior}

There is also a behavioural requirement for bulls to be able to successfully establish pregnancy. Bulls must be able to both identify females in estrus and be able to mount them, both of these traits are unrelated to semen quality or traits measured during the breeding soundness evaluation (Galina et al. 2007). 
Bulls use both sight and smell to locate and detect cows that are in estrus (Blockey 1976b). Bulls look for cues such as mounting or being mounted by other cows, or a change in posture where the cow will arch her back and raise her tail (Hamond 1927). The bull will also sniff the vulva of the cow to determine if the cow is in standing heat, the amount the bull relies on his olfactory skills depends on the presence or absence of the aforementioned physical signs (Blockey 1979b).

In a review of the literature on sexual behaviour in bulls, Blockey (1979b) describes the process that takes place once a bull has located a female in estrus. The bull begins by standing behind the cow and licking and sniffing around the vulva, the bull will then signal its intention to mount usually by resting its chin on the cows back. If the cow is still responsive the bull will mount lifting its front end off the ground high enough to situate himself on the back of the cow and hold himself in place using his front legs. The bull then makes a series of pelvic thrusting movements known as "seeking movements" to bring the tip of the penis into the vaginal orifice. At this time, the sigmoid flexure straightens and the penis lengthens allowing the penis to penetrate the vagina and ejaculation occurs (Blockey 1979b).

\subsubsection{Environment}

Environment is known to play an important role in bull fertility, as the time of year that a bull is tested, temperature, weather conditions, and other environmental stress factors are shown to directly affect semen production and quality (Stalhammar et al. 1989; Fiaz et al. 2010). Environmental effects on semen production and quality will vary greatly with location and whether a bull is adapted to a climate or new to that climate (Fields et al. 1979; Brito et al. 2002).

Breeding pasture size can also play an important role on bull fertility. In larger pastures, 
bulls must actively seek out cycling females (Blockey 1979b), but bulls that are younger and less socially dominant have an opportunity to escape from more dominant bulls (Fordyce et al. 2002). Fordyce et al. (2002) showed that in large pastures with a lower bull:cow ratio, dominant bulls tended to travel lesser distances and breed more cows, whereas bulls that were lower on the social dominance scale were more likely to travel larger distances.

Since bulls from multi-sire breeding pastures are in the same climate, environment should not play a role from bull to bull within a breeding pasture, only between breeding pastures (Van Eenennaam et al. 2007). Because changes in semen quality are affected by adaptability, environment could play a role within a breeding pasture if some bulls were brought in from a different region or climate other than the local environment at the breeding pastures (Fields et al. 1979).

\subsubsection{Nutrition}

It is generally accepted that nutrition management is one of the major limiting factors for fertility (Short and Adams 1988). Nutrition plays an important role in all aspects of fertility; SC and therefore semen output and concentration (Hahn et al. 1969), endocrinology, semen quality, and libido are all affected to some degree by nutrition. In most cases, excess or inadequate energy is the main cause of decreased fertility but when protein is limited severe problems can arise as well (Rekwot et al. 1987).

Mwansa and Makarechian (1991) showed that bulls that were maintained on a highenergy diet throughout the course of the study showed an increased number of sperm abnormalities than those maintained on a low energy diet or those that switched from high to low or low to high. Although severely overfeeding bulls seems to result in fat deposition in the 
scrotum resulting in reduced sperm quality (Mwansa and Makarechian 1991), moderately overfeeding bulls can also be detrimental to bull fertility but most likely due to decreased libido not reduced semen quality (National Academies of Sciences, Engineering, and Medicine 2016). Although Mwansa and Makarechian (1991) suggest that bulls should not be maintained on a high-energy diet, it is also important not to restrict diet too much. VanDemark et al. (1964) showed that when bulls were restricted to $60 \%$ of the recommended total digestible nutrients (TDN) a reduction in semen production and number of sperm per ejaculate was found and bulls never fully recovered to their maximum semen production.

Little work has been completed to evaluate the effect of different protein levels in a diet and its effect of bull fertility. The few studies that have been conducted, concluded that bulls on a low protein diet have decreased volume of semen, sperm motility, semen concentrate, and total spermatozoa when compared to those on a high protein diet (Meacham et al. 1963; Rekwot et al. 1988).

Moderate deficiencies or excess in protein and energy do not appear to have an effect on factors affecting a bull's ability to sire calves (National Academies of Sciences, Engineering, and Medicine 2016). Severe deprivation of protein, energy, or water is needed to result in permanent damage and the reduction or a complete stop of spermatogenesis (National Academies of Sciences, Engineering, and Medicine 2016).

Although limited work is available on bull nutrient requirements, the National Academies of Sciences, Engineering, and Medicine (2016) still provides recommendations for nutrient requirements for both growing and breeding bulls. Depending on bull weight and growth targets it is recommended that bulls have a DMI of 6.51 to $19.39 \mathrm{~kg}$ per day, of that, crude protein (CP) should be incorporated at 7.3 to $19.4 \%$ of the total diet dry matter (DM) (National Academies of 
Sciences, Engineering, and Medicine 2016).

\subsubsection{Management factors}

Management of the cow herd and breeding season length and time will play an important role on the ability of a sire to establish pregnancy in fertile females. Even highly fertile bulls may not be able to establish pregnancy in cows when the bull to cow ratio is too high resulting in a larger number of open cows due to overuse of bulls (Parkinson 2004). To address this issue, Fordyce et al. (2002) showed in a 3-yr study that reducing the number of cows compared to bulls from $3.7 \%$ to $2.8 \%$ did not result in reduced conception rates or delay conception. The ratio change resulted in a change from 27 cows per 1 bull to 35 cows per bull (Fordyce et al. 2002). These ratios are higher than the 24 cows per bull that is the average across western Canada (Larson 2015), but is still less than the 40 cows per bull recommended by Hamilton (2006).

Numerous research papers have suggested that bulls become sexually saturated, and decrease the number of services when exposed to the same sexual experience more than once within a short time frame (Almquist and Hale 1956; Chenoweth 1982; Blockey 1981). In one review, Chenoweth (1981) showed that bulls experienced sexual exhaustion anywhere between 9 to 83 services in $24 \mathrm{~h}$ but that number changed to 20 to 55 services per $\mathrm{d}$ in studies that lasted longer than one day. Blockey (1981) showed that when bulls were exposed to a restrained heifer $2 \mathrm{~d}$ in a row, bulls achieved 50 percent less services on the second day than they did in the initial test.

\subsubsection{Breed}

Although breed does play a role in fertility, it has a much smaller impact than the many above mentioned factors. Breed effects may be used to explain why some cattle show large 
correlations with factors such as social dominance, libido and testicular traits and number of calves sired, whereas other breeds show a lower degree of correlation (Holroyd et al. 2002). A study by Waldner et al. (2010) showed that breed was associated with differences in SC, percent normal sperm and percent live sperm $(\mathrm{p}<0.05)$ but not in percent motile sperm $(\mathrm{p}=0.41)$. Previous studies have also shown differences in fertility between purebred and crossbred bulls (Chenoweth and Osborne 1975) but very little work has been conducted on crossbred bulls.

\subsubsection{Interaction between the cow and bull for reproductive success}

In some cases, pregnancy rates may be used as a measure of bull fertility, however this can be a problem as conception rate, pregnancy rate, and calving rate are often used interchangeably but have different meanings. Conception rate is the number of successful pregnancies in relations to the number of service attempts and is more commonly used with artificial insemination (AI; LeBlanc 2010). Pregnancy rate is defined as the number of cows out of the group that have become pregnant, and calving rate is the number of calves born in a specific group of exposed cows (LeBlanc, 2010). Using any one of these to determine bull fertility may be inaccurate because the calculation does not take into consideration the cow or early embryonic losses. (LeBlanc 2010). It has been predicted that 75 to 80 percent of all embryonic losses occur within $20 \mathrm{~d}$ of pregnancy (Sreenan and Diskin 1983). If calving rates, or pregnancy rates are being used to determine bull fertility these losses would not be attributed to the bull as there would be no signs that the cow was pregnant and she would return to estrus.

Successful establishment of pregnancy is more useful when evaluating whole herd nutrition and performance compared to individual bull performance (Kastelic and Thundathil 2008). Ultimately the contribution of the bull to each individual pregnancy is minor in 
comparison to the dam (Linford et al. 1976). Using both calving rate along with DNA parentage testing results may allow producers to fairly evaluate individual bull performance.

\subsubsection{Use of multi-sire breeding pastures in western Canada}

With the decrease in number of beef cattle herds and increase in herd size, multi-sire breeding pastures are becoming even more common in western Canada (Statistics Canada, 2012). Multi-sire breeding pastures are also popular in community pasture settings across western Canada. Multi-sire breeding pastures may allow producers economic gain by increasing fertility rates, reducing calving interval, and minimizing the number of pastures needed when compared to single sire pastures, and protecting against single sire breeding failure (Lunstra, 1985; Van Eenennaam and Drake 2012)

In commercial practice, the assumption is that the number of calves sired is equal for each bull, even though this has been shown to not be the case (Van Eenennaam et al. 2007; Van Eenennaam et al. 2014). Using DNA parentage verification is currently the only accurate way to determine the actual value of a sire, but due to the time required to take DNA samples, and the large, upfront costs, it has not been readily adopted by industry (Larson, 2015)

\subsection{Sire verification}

\subsubsection{Sire verification in the purebred industry}

In the Canadian purebred industry, sire parentage verification is commonplace and for many purebred breed associations it is mandatory (Van Eenennaam and Drake 2012). Parentage testing is used to maintain breed purity and integrity within the purebred or seedstock industry (Van Eenennaam and Drake 2012). In some situations, bulls that are sold for breeding purposes 
are required to be sire verified, in others, random spot checks of DNA sire verification are completed to uphold the integrity of the breeder marketing bulls and the breed itself (Canadian Angus Association, 2011).

\subsubsection{Sire verification in multi-sire breeding pastures}

Sire verification is an important tool for several reasons, including knowledge of which calves came from which bulls. Sire verification also allows producers to make culling decisions for bulls that are not prolific or not producing top quality calves (Van Eenennaam et al. 2007). Knowing which bulls are the most prolific and what traits bulls may be passing on to their progeny can also assist in the decision of which calves to keep as replacement heifers (Van Eenennaam and Drake 2012). Since bulls contribute 50 percent of the genetics of a herd, a fertile bull is essential to ensure that all cows are bred within $82 \mathrm{~d}$ after calving so that every cow will have a calf every 365 days (Van Arendonk et al. 1989). If a bull is unable to breed the desired number of cows during the defined breeding season this may cause increased culling rates of cows, delayed conception and reduce the number of calves born, all resulting in a major economic loss to the enterprise (Van Arendonk et al. 1989).

Anecdotally, it is assumed that producers who are using multi-sire breeding pastures are unable to accurately determine the number of calves a bull has sired and by association the value of the bull. In a study by Hamilton (2006), the industry standard suggested bull:cow ratio was 10 cows for every yearling bull and no more than 40 for every mature bull, however an assumption cannot be made that each bull is siring the same amount of calves. Van Eenennaam et al. (2007), reported that in multi-sire breeding pastures bulls sired anywhere from 0 to greater than $50 \%$ of all calves born in the calving season. However, the bulls that are siring no progeny are still 
accumulating the same costs as those bulls that are siring a large proportion of the calf crop, but there is no economic return on investment for these bulls (Van Eenennaam et al. 2007).

Producer observations during the breeding season may not be an accurate tool to use for sire verification of all calves born. Even when producers are able to observe breeding this may not be enough as it is suggested that the majority of heifers in multi-sire breeding pastures are serviced by more than one bull (Farin et al. 1982).

\subsection{Repeatability of prolificacy of breeding}

Using DNA parentage verification to make sire selections is only effective if prolificacy of the bull is repeatable from year to year, and if this is the case then it is safe to cull a bull because he has sired a low number of calves without fear that it was just a poor year. In a $3 \mathrm{yr}$ study, Holroyd et al. (2002) concluded that bull prolificacy is a moderately repeatable trait in mature bulls, meaning that it can be relied on for sire selection and retention. Although not all bulls in the study were present for more than one breeding season, Van Eenennaam et al. (2007) also found that for the mature bulls in the study that were around longer than one breeding season, the number of calves sired was moderately repeatable. There has been no research conducted looking specifically at repeatability of number of calves sired, more work in this area would be useful in increasing commercial producer adoption of DNA parentage testing

\subsection{DNA parentage testing and techniques}

DNA parentage testing is a simple and accurate way to determine parentage in multi-sire breeding pastures (Holroyd et al. 2002; Van Eenennaam et al. 2007). Problems can arise when a 
sire cannot be verified as even with the most accurate of lab tests there are still genotyping errors that occur and errors where the sire could not be accounted for, such as in a situation where the neighbor bull invaded the pasture (Van Eenennaam et al. 2007). Even with these problems, DNA parentage verification is still considered to be the most efficient way to determine a sire's contribution to an operation that utilizes multi-sire breeding pastures.

\subsubsection{Single nucleotide polymorphism}

Although there are many types of molecular markers that can be used to determine parentage, there has been a movement towards the use of single nucleotide polymorphism (SNP) testing (Heaton et al. 2002; Vignal et al. 2002). The shift towards SNP technology is due to many factors including low genotype error rates, decreased cost, ease of standardization across laboratories for genotype scoring, and ease of automation (Anderson and Garza 2006).

The accuracy of assigning parentage increases as the number of SNPs increases, but more SNPs are more expensive and eventually the increased accuracy is not worth the increased cost (Strucken et al. 2016; Buchanan et al. 2016). Accuracy can also be increased if DNA information is available for both parents (Buchanan et al. 2016). At the time of this study common industry practice was to use a 100 SNP panel to determine parentage (Van Eenennaam et al. 2012; Deobald 2015). Recent research suggests that in a large population size where pedigrees are unknown a 100 SNP panel may not be enough to accurately assign parentage (Buchanan et al. 2016). This study suggested that 200 or more SNPs may be a better choice to accurately assign parentage in large commercial herds (Buchanan et al. 2016). 


\subsubsection{SNP testing and economic value}

With the easy standardization and automation of SNP testing there is real potential for this method to become more popular in commercial practice (Anderson and Garza 2006). Although little research has been conducted as to the economic value of using DNA parentage testing to make culling decisions within a herd it is known that the number of years that a bull remains in the herd plays a significant role in the return on investment for progeny testing (Van Eenennaam et al. 2007).

As SNP technology advances, the cost of sire verification has been decreasing and the ease of incorporating it into commercial practice has been increasing (Wiggins et al. 2011). With current SNP technology, there is no need to take blood samples which are difficult to handle, store, and transport (Curi and Lopes 2002). Hair and tissue samples used for SNP testing can be easily collected and stored by commercial producers on farm (Anderson and Garza 2006).

\subsection{Alternatives to full DNA parentage testing programs}

Depending what the purpose of DNA parentage testing is, there are other options for producers than testing the entire calf crop born during the calving season. Instead of testing the entire herd beef producers have the option to test just calves that had a difficult birth, or only a portion of the herd born at the beginning of the calving season. Preliminary work by Van Eenennan et al. (2014) suggests that only testing a portion of the calf crop may give producers an accurate reflection of bull prolificacy at a lower cost and faster turnaround time than testing the whole herd. 


\subsubsection{Identifying sires causing dystocia}

Many factors play a role in dystocia rates in a cow-calf herd including dam breed, dam age, calf sex, and calf birth body weight and proportion (skeletal vs. muscle; Laster et al. 1973; Meijering 1984). Dystocia not only results in both cow and calf injury, disease, and/or death during or shortly after pregnancy, long term effects such as lower estrus detection rates, lower conception rates, and longer times from calving to first breeding also occur with cows who have experienced dystocia (Laster et al. 1973)

Individual bull characteristics have been shown to play a role in dystocia, Bellows et al. (1982) was able to increase dystocia rates in heifers and cows by choosing bulls based on progeny test information. The problem is that for young sires, progeny information is not available for the producer when purchasing the sire. DNA parentage testing allows producers to collect that information for themselves (Van Eenennaam and Drake 2012). In addition, testing only calves from cows that experienced dystocia would be cheaper than testing the entire calf crop, and if the majority of calves were from one sire it would provide justification to cull the problem sire.

\subsubsection{DNA testing a portion of the calf crop}

A recent paper by Van Eenennaam et al. (2014) evaluated only DNA testing a portion of the calf crop. Two different subsets of calves were DNA tested, calves born only in week 3 of calving or calves born in week 2, 3, and 4. These 2 subsets were compared to sampling the entire calf crop. When only calves born in the third week were sampled only $1.4 \%$ of bulls that were classified as high prolificacy when the entire herd was sampled were considered to be low 
prolificacy. When only calves born in weeks 2,3 , and 4 were evaluated none of the high prolificacy bulls were reassigned to the low prolificacy breeding group. For both methods of alternate testing, less than 3\% of low prolificacy bulls were reclassified as high prolificacy (Van Eenennaam et al. 2014). This suggests that if producers are able to take the DNA sample at birth, or keep production records on calving dates these methods may be acceptable to reduce the cost of testing an entire calf crop.

\subsection{Summary of literature review}

Beef producers are searching for new technologies that can improve production management and ultimately profitability on their operation. Using DNA parentage testing is a technology that has decreased in cost in recent years making it more attractive to commercial cow-calf producers.

However, there are many factors that can influence the prolificacy of a herd sire including age, breed, physical soundness, nutritional status, and spermatological factors. There are also multiple factors that cannot be easily tested on beef operations that can contribute to the bull's ability to sire calves. These include libido, social dominance, and interactions with the cow herd. Using DNA parentage testing allows producers to retroactively and confidently evaluate bull fertility. It is hypothesized that each bull in a multi-sire breeding pasture will sire an equal number of progeny during the breeding season. 


\subsection{EVALUTION OF BULL PROLIFICACY IN MULT-SIRE BREEDING SYSTEMS}

\subsection{Introduction}

In western Canada, natural breeding using multi-sire breeding pastures is the most common method of breeding cows (Larson 2015). However, a disadvantage of using multi-sire breeding is that there is no way of knowing which bulls are producing calves. Using DNA parentage may allow producers to confidently assign parentage to bulls in multi-sire pastures.

In most commercial cow-calf operations new genetics are introduced into the herd primarily through the purchase of new bulls with the assumption that each bull in a pasture will sire the same number of calves (Larson 2013). A recent study has shown that bulls in multi-sire pastures sired anywhere from 0 to greater than $50 \%$ of the annual calf crop (Van Eenennaam et al. 2007). This suggests that producers may be paying a high purchase price for bulls to advance the genetics in their herds, when the bull is actually contributing very little.

According to the Western Canadian Cow Calf study, only 13\% of bulls culled in 2014 were culled due to progeny performance (Larson 2015). This suggests that producers may not be aware of how progeny from individual bulls are performing. Using DNA parentage testing may allow producers an opportunity to evaluate progeny performance of individual bulls (Van Eenennaam et al. 2007).

Producers can reduce the chance that bulls will potentially sire a low number of calves by ensuring that bulls have passed the breeding soundness evaluation (BSE) before being turned out to breed cows, but this alone is not a guarantee that they will go out and breed cows (Farin et al. 1989). Just because the potential for a bull to breed cows exists, doesn't mean that the bull actually will have high libido and breed. 
There has been limited research conducted into which specific traits may cause some bulls to be more prolific than others (Blockey 1979; Barth and Oko 1981; Stalhammar et al. 1989; Holroyd et al. 2002; Van Eenennaam et al. 2007). It is also known that semen quality and quantity are effected by bull age (Stalhammar et al. 1989). Although this would suggest that younger bulls should sire less calves, that is not necessarily the case if young bulls have adequate semen quality to pass a breeding soundness exam. Spermatological factors are also known to play a role in fertility Chenoweth et al. (1992) showed that values for a BSE are set because any lower values have been shown to be detrimental to pregnancy rates, however higher values have not been shown to increase pregnancy rates. The values outlined in a BSE exam to rank sires were determined when bulls were in isolation, so it is not known how spermatological factors can affect the number of calves sired by a bull in a multi-sire system.

Scrotal circumference of the sire can also play a role in the number of calves that are sired and are therefore included in the BSE (Barth 1989). Scrotal circumference is known to be related, but not correlated to fertility (Barth 1989). Scrotal circumference is highly correlated with age so the lower fertility rates observed in young bulls is also often observed in bulls with a lower scrotal circumference.

There has been limited research evaluating the use of DNA parentage testing in commercial cow-calf operations and the different numbers of calves sired by each bull and why some sire more calves than other. Therefore, the objectives of the following study were (1) to evaluate paternity laboratory test results as a method of evaluating the sires contribution to an operation that uses multi-sire breeding pastures; (2) to determine the association between sire age and other factors affecting number of progeny per sire in multi-sire breeding pastures; (3) to use paternity results to calculate bull cost per calf sired, and calf income generated per sire as a 
means of assessing sire economic value to an operation; and (4) to determine if using DNA genomic information to determine parentage is cost effective and valuable for culling nonprolific sires.

\subsection{MATERIALS AND METHODS}

Data collection involved collaboration with four ranches in Saskatchewan evaluating the use of sire DNA verification on commercial cow-calf operations.

\subsubsection{Collaborating ranches}

Four commercial ranches, defined as A, B, C and D with variation in breeds used and management practices were used for this study. The four ranches were located at Shaunavon, Ituna, Kelliher and Lanigan, Saskatchewan. A detailed outline for each operation showing the different timelines for each stage of production at all 4 ranches is reported in Appendix A.

\subsubsection{Ranch A}

Ranch A was located at Shaunavon, Saskatchewan. There were 400 cows mainly composed of Angus-Hereford crossbred cows, and 18 bulls consisting of Red Angus and Beef Booster breeds. The breeding season was 56 to $59 \mathrm{~d}$ managed in four separate breeding pastures with herd sizes of 66 to 130 cows per pasture and 3 to 6 bulls in each pasture. The bull to cow ratio ranged from 1:21 to 1:29. A total of 394 samples were submitted to the lab for testing. 


\subsubsection{Ranch B}

Ranch B was located at Ituna, Saskatchewan. Although there were 1500 cows at Ranch B, the study involved only 200 Red and Black Angus-Hereford crossbred cows and eight Black Angus bulls. The breeding season was $57 \mathrm{~d}$ in length with all 200 cows and eight bulls in one pasture, and a bull to cow ratio of 1:24. A total of 194 samples were submitted to the lab for testing.

\subsubsection{Ranch C}

Ranch C was located at Kelliher Saskatchewan. Of the approximately 1,000 cows at this ranch this study focused on one breeding group of approximately 110 cross-bred first calf heifers. The breeding season for this group was $123 \mathrm{~d}$ with all heifers in one breeding pasture with eight composite bulls plus a neighbour's bull who invaded the pasture for a portion of the breeding season. The bull to cow ratio in Ranch $\mathrm{C}$ was approximately 1:12 and a total of 108 samples were submitted to the lab for testing.

\subsubsection{Ranch D}

Ranch D is Western Beef Development Centre (WBDC) Termuende Research Ranch, located at Lanigan, Saskatchewan. Although there were 350 cows at this ranch, this study focused on one breeding group with 101 Black Angus females and four Black Angus bulls. All 101 cows and four bulls were managed in one breeding pasture. The breeding season for this group was $67 \mathrm{~d}$ in length with one bull removed at $34 \mathrm{~d}$ due to injury. The bull to cow ratio at Ranch D was 1:25 and a total of 93 samples were submitted to the lab for testing. 


\subsubsection{Data collection}

Before breeding season began, a breeding soundness examination was conducted on all bulls by a licensed veterinarian. Data collected included percent normal sperm, scrotal circumference, sperm abnormalities, BCS, and bull age. Additional data included bull:cow ratio, breeding season length, number of bulls and cows in each breeding pasture and number of calves born per pasture. Economic data included purchase price of bulls and sale price of calves at weaning.

\subsubsection{DNA collection on bulls and calves}

All bulls where collected for DNA analysis by sampling tail hairs and any other possible sires such as bulls from neighboring fields that invaded the herd, were tested. Approximately 20 hairs where pulled out of the tail with the follicle attached. Hair strands were then sealed in a paper envelope to avoid moisture contamination and stored in a dry location until processing.

DNA collection on calves was conducted using a tissue sampling applicator (Quantum Genetix, Saskatoon, SK), with samples taken when other management procedures were performed such as at branding, vaccinating, or weaning. All tissue samples were frozen until delivery to the laboratory.

\subsubsection{Breeding soundness examination}

Prior to breeding all bulls underwent a BSE outlined by the Western Canadian Association of Bovine Practitioners (WCABP; Barth, 2013) which was carried out by licensed veterinarians. Semen was collected from all bulls through the use of electroejaculation techniques or massage of the vesicular gland and ampullae. Bulls were also examined for any 
injuries or abnormalities that may limit their prolificacy including non-erection during electroejaculation, feet or leg injuries or eye injuries. In three of the breeding herds only bulls that passed the breeding soundness exam were allowed into the breeding pasture. An exception was in ranch $\mathrm{C}$ where a neighbor bull and two yearling bulls who did not have a BSE conducted were mistakenly admitted into the field.

\subsubsection{Sire verification}

All DNA samples were analyzed at Quantum Genetix Ltd., Saskatoon, Saskatchewan using SNP technology for sire verification. Samples underwent DNA extraction using either sodium hydroxide lysis or paramagnetic bead (company, city, state) DNA extraction. Once the DNA was extracted from either the hair or ear tissue sample, the final dilutions were used as templates in qRT-PCR genotyping reactions. The reactions were run as a multiplex to reveal the status of four alleles per reaction (two of one SNP and two of another SNP). Since information from 100 SNP's is used in sire verification a minimum of 50 multiplex reactions must be run per DNA sample. When a correct sire could not be identified using the 100 SNP panel, additional SNP's were tested, if a sire could still not be determined the calf was classified as 'no sire match'.

\subsubsection{Statistical analyses}

Statistical analysis was performed using SAS (SAS Version 9.2; SAS Institute Inc., Cary, NC). Chi-square analysis was used to determine differences between observed and expected number of progeny sired by each bull. The observed frequency was the number of calves sired by each bull, and the expected frequency was the number of cows per pasture / number of bulls 
per pasture. To analyze the effect of age on number of calves sired by each bull these variables were independently tested utilizing the Chi-squared analysis of SAS (SAS Institute Inc., Cary, $\mathrm{NC}$ ). Differences were considered significant at $\mathrm{P} \leq 0.05$.

For other factors, the coefficient of determination or $\mathrm{R}^{2}$ values were calculated to determine if there was a correlation between each factor and a bull prolificacy index (BPI). A BPI was developed to account for differences in bull to cow ratios between breeding groups.

Each bull BPI was calculated using the following equation.

BPI= number of calves sampled that were sired by a specific bull / (number calves born/total bulls in the breeding pasture) (Campbell 2016). BPI was calculated for each bull to eliminate the effects of pregnancy rates and bull:cow ratio on bull prolificacy.

Using number of calves sampled in the BPI calculation represents a crude estimate of the number of cows that became pregnant and calved as this data was not available for every farm. By not including cows that were found to be 'open' or not pregnant in the denominator a BPI calculation was automatically that adjusts for a low pregnancy rate that may be caused by cowrelated factors such as poor nutrition. In each breeding pasture calves that were born dead or died shortly after birth (before processing where samples were collected for the rest of the herd) had DNA samples sent to the lab. Since all calves born were sampled the number of calves sampled in each herd is equivalent to the number of cows exposed $\mathrm{x}$ pregnancy rate. The BPI shows which bulls are siring more than or less than the expected number of progeny. To interpret the results of the BPI, a BPI approximately equal to1 means bulls are siring the same amount of calves they are expected to sire if each bull sired an equivalent number of calves in the pasture. 
A BPI $<1$ means calves are siring less calves than would be expected and a BPI $>1$ means bulls are siring more calves than expected. In each case, the BPI assumes that each bull has an equal opportunity to breed an equivalent number of cows within a multi-sire pasture. If an initial correlation was detected among the variables tested and BPI further analysis was performed using the Chi-squared test.

To determine the degree to which The BSE per bull calculated by testing only calves born in week three or in the first $21 \mathrm{~d}$ of the calving season agreed with the total calculated BSE Fleiss' Kappa statistic was calculated. Fleiss' Kappa statistic was calculated individually for how week three results compared to the total as well as how $21 \mathrm{~d}$ results agreed with the total results.

\subsection{RESULTS AND DISCUSSION}

\subsubsection{Bull prolificacy}

Bull prolificacy varied within breeding groups at each ranch. Descriptive statistics for number of calves sired per bull in a breeding group are presented in Table 3.1

\section{Table 3.1 Descriptive statistics on number of calves sired per bull in each breeding group}

\begin{tabular}{ccccc}
\hline & & \multicolumn{3}{c}{ Number of calves sired per bull } \\
\cline { 2 - 5 } Ranch/breeding group & Number of bulls & Average & Maximum & Minimum \\
\hline A1 & 8 & 26 & 44 & 10 \\
A2 & 6 & 21 & 53 & 5 \\
A3 & 3 & 21 & 29 & 14 \\
A4 & 4 & 18 & 24 & 12 \\
B5 & 8 & 23 & 46 & 5 \\
C6 & 9 & 11 & 34 & 1 \\
D7 & 4 & 22 & 30 & 14 \\
\hline
\end{tabular}

Large variation was observed in the number of calves sired by each bull in a breeding pasture (Table 3.1). This is consistent with previous research by Holroyd et al. (2002) and Van 
Eenennaam et al. (2007). Of the 235 bulls used in the study by Holroyd et al. (2002) $58 \%$ of bulls sired less than $10 \%$ of calves in their breeding groups. Both Van Eenennaam et al. (2007) and Holroyd et al. (2002) observed bulls in breeding groups that did not sire any calves. In the current study, all bulls sired at least one calf, most likely due to the lower number of bulls in the current study as compared to the others mentioned.

Godfrey and Lunstra (1989) tested bulls for serving capacity individually. When bulls with high serving capacity were grouped together and retested for serving capacity within the group they were observed to have even higher serving capacity scores then when they were tested individually. This trend is not observed in bulls with a low serving capacity score when tested alone, indicating that bulls with a high serving capacity may attempt to breed more cows in the presence of other bulls (Godfrey and Lunstra 1989). Although serving capacity was not tested in the current study, the trend was still observed, the breeding groups with the highest number of bulls in each pasture A1, A2, B5, and C6 were also the groups with the highest maximum number of calves sired by individual bulls (Table 3.1). Serving capacity is a way of measuring bull libido (Blockey 1981). Since libido relates to a bull's ability to actually service cows (Coulter and Kozub 1989) it can be assumed that, even though a SCT was not performed, the bulls siring the maximum number of calves in those individual breeding pastures were the high libido bulls. That being said, although bulls siring the maximum number of calves are more likely to be the high libido bulls, factors such as injury or poor semen quality could prevent high libido bulls from siring a high number of calves.

Breeding groups with lower number of bulls in the pasture showed less variation in range of number of calves sired compared to those with a higher number of bulls in the breeding group (Table 3.1). This effect may have been due to social interaction between bulls. Previous work 
has shown that when bull number in a breeding pasture increases there is more of an opportunity for a dominance hierarchy to be established (Price and Wallach 1991). Price and Wallach (1991) observed that increasing the number of bulls during libido tests caused an increase in aggression between bulls and reduced overall sexual activity. Aggression between bulls may have played a role in the greater variation in BPI values in the current study.

Past research has established that when greater than 12 bulls are in a breeding pasture, bulls are no longer able to establish a stable social dominance hierarchy. (Schein and Fohrman 1955; Wagnon et al. 1966). Social dominance order and the stability of social dominance are known to effect sexual activity (Blockey et al. 1979). Since the current study did not have any breeding groups with greater than 9 sires it can be assumed there was a linear relationship of social dominance order and that the order, once established, remained relatively constant. Therefore, it is possible that the bulls in the larger breeding groups were able to establish a social dominance order resulting in an increased variation in number of calves sired as the sire number increased. Future research is needed to establish if bulls in breeding groups greater than 12 sires would result in increased variation in the number of calves sired or if the variation in number of calves sired would plateau as bull number increased. Chi-square analysis results evaluating bull prolificacy within a breeding group are presented in Table 3.2. 
Table 3.2 Results of Chi square analysis comparing observed vs expected progeny per bull in each breeding group

\begin{tabular}{ccccc}
\hline Ranch/breeding group & $\begin{array}{c}\text { number of } \\
\text { bulls. }\end{array}$ & Chi Square & DF $^{\mathrm{z}}$ & P-value \\
\hline A1 & 8 & 31.31 & 4 & $<.01$ \\
A2 & 6 & 73.30 & 5 & $<.01$ \\
A3 & 3 & 5.43 & 2 & 0.07 \\
A4 & 4 & 4.63 & 3 & 0.20 \\
B5 & 8 & 80.65 & 7 & $<.01$ \\
C6 & 9 & 100.56 & 8 & $<.01$ \\
D7 & 4 & 10.82 & 3 & $<.01$
\end{tabular}

${ }^{\mathrm{D}} \overline{\mathrm{DF}}=$ degrees of freedom.

In five of the seven breeding groups evaluated, bulls in each group sired significantly $(\mathrm{P}=0.01)$ different number of calves than what was expected (Table 3.2). This is similar to results from Van Eenennaam et al. (2014) who found that the number of calves sired by each bull in a breeding pasture (group) was highly variable ( $\mathrm{P}<0.01$ to 0.20$)$. Holroyd et al. (2002), also observed variations in number of calves sired by bulls in the same breeding pasture. In the current study, bulls in breeding groups A3 and A4 were not found to sire statistically different $(\mathrm{P}>0.05)$ numbers of calves than expected, which was most likely due to the low number of sires in those pasture groups, with 3 and 4 sires per breeding group A3 and A4, respectively.

A large variation in number of calves sired $(\mathrm{P}<0.05)$ by individual bulls was also observed by McCosker et al. (1989) who studied primarily Bos indicus bulls. In the study, the authors were investigating low reproductive rates in multi-sire groups and found certain bulls to be responsible, as culling these animals eliminated the problem (McCosker et al. 1989). A particular study pasture had a large percentage of bulls with $>40 \%$ over 8 yr of age, which was found to contribute to the large variation observed, it was assumed that the older bulls were still 
dominant and prevented other bulls from servicing cows but were not able to establish pregnancy in cows themselves (McCosker et al. 1989).

In two of the herds evaluated in a study by Van Eenennaam et al. (2014), there were reported to be only two to five sires in each breeding pasture, yet differences $(\mathrm{P}<0.05)$ in number of calves sired by each bull were reported. The differences in how the data were analyzed between the study by Van Eenennaam et al (2014) and the current study is most likely what contributed to the difference in number of calves sired between the two studies. In the current study bulls were only compared to other bulls in the same breeding group to evaluate specific breeding group effects (age, spermatological characteristics) that may influence bull fertility.

The BPI index is based on actual pregnancy rates, however only sampling the number of calves born, the index does not account for incidences of early embryonic loss (Campbell 2016). It is known that in beef cattle, low embryo survival rates can result in low pregnancy rates (Rowlands and Weir 1984). Low embryo survival rates cannot be influenced by bull management so basing BPI on calves born only accounts for bull factors that affect fertility.

\subsubsection{Bull to cow ratio}

There was a large variation among the calculated BPI for all sires, with the lowest being 0.08 and the greatest 2.83 with a standard deviation of 0.66 (Table 3.3). The mean for all the data presented in Table 3.3 was 0.97 , an expected mean of 1 was not achieved this was most likely due to the error associated with not all calves being assigned a sire. The BPI was further used to compare all factors that were measured, both on an individual bull level and an overall herd level. 
Table 3.3 Number of sires and bull to cow ratio for each breeding group and the corresponding range in BPI for each group

\begin{tabular}{cccc}
\hline Ranch/breeding group & Number of sires & Bull to cow ratio $^{\mathrm{z}}$ & Range of BPI \\
\hline A1 & 8 & $1: 26$ & $0.33-1.69$ \\
A2 & 6 & $1: 21.3$ & $0.23-2.48$ \\
A3 & 3 & $1: 22$ & $0.64-1.32$ \\
A4 & 4 & $1: 17.5$ & $0.69-1.37$ \\
B5 & 8 & $1: 24.3$ & $0.21-1.90$ \\
C6 & 9 & $1: 12$ & $0.08-2.83$ \\
D7 & 4 & $1: 23.3$ & $0.60-1.29$ \\
\hline
\end{tabular}

${ }^{\mathrm{z}}$ When bull to cow ratio was not available estimates where made based on number of calves sampled in each breeding group.

Breeding pasture size was not measured in the current study but may have played a role in number of calves sired by each bull. Fordyce et al. (2002) suggested that in larger pastures, younger and less socially dominant sires have an opportunity to escape from older more dominant bulls and are therefore able to sire more calves. Breeding group C6 had a bull to cow ratio much higher than the other breeding groups (Table 3.3). If these bulls were in a smaller group/pasture it would make sense that the less dominant bulls would not be able to escape from the more dominant bulls resulting in the large variation in BPI in that pasture.

Research conducted by Godfrey and Lunstra (1989) suggested that high libido bulls had even higher serving capacity scores when grouped with other bulls which may also explain the variation in BPI that was associated with the breeding group C6 high bull:cow ratio. If the bulls in this pasture who were high-libido bulls to begin with had increased libido due to the presence of other bulls it would make sense that the high-libido bulls would sire most of the cows resulting in the rest of the bulls being able to only service a limited number of cows.

In single sire mating groups Godfrey and Lunstra (1989) found that when bulls with low serving capacity were exposed to cows, there was no difference $(\mathrm{P}>0.10)$ in conception rates in single sire mating groups compared to high serving capacity sires. In contrast when high and low 
serving capacity bulls were combined in a breeding pasture there was a difference $(\mathrm{P}=0.01)$ in number of services (Godfrey and Lumstra 1989) This suggests that bulls with lower libido may under perform in multi-sire pastures. This may be why bulls in group C6 had the largest variation in BPI (0.08-2.83; Table 3.3), even though the bulls were capable of establishing pregnancy there was more competition resulting in a low number of calves sired by some bulls and a much higher percentage sired by other bulls.

No conclusions could be made with respect to the effect of bull to cow ratio on bull prolificacy due to low numbers of breeding pastures (groups), but it was observed that lower bull to cow ratios resulted in less variation of BPI values (Table 3.3). This would suggest that those bulls that were exposed to more cows are more efficient and effective at getting cows serviced and pregnant. This also suggests that as bulls are exposed to more cows, there is a higher likelihood of at least one cow being in heat at any particular time and as a result bulls will be spending more time seeking out females in standing heat and less time fighting. Farin et al. (1982) showed that in a two-sire breeding pasture study, $50 \%$ of synchronized heifers were serviced by both bulls but did not differ $(\mathrm{P}>0.05)$ for heifer pregnancy rates in a single bull pasture. This further suggests that bulls in multi-sire breeding pastures with more cows in estrous are allocating their time to breeding those cows in estrous and ignoring other bulls.

There is debate in the literature about the effect of bull:cow ratio on fertility and conception rates. Some researchers have found differences in the number of times cows were mated as bull:cow ratio changed but no overall difference in pregnancy rates (Rupp et al. 1977). In contrast, Beerwinkle (1974) found that as bull to cow ratio increased, mounting activity decreased. Since Beerwinkle (1974) did not measure actual pregnancy rates it can't be determined if fertility was actually influenced or if bulls in pastures with higher bull:cow ratios 
were just more efficient at breeding cows. Some researchers have argued that individual bull fertility and libido plays a greater role in overall fertility and pregnancy rates than does the bull:cow ratio (Rupp et al. 1977).

Larson (2015) reported that the average bull to cow ratio across western Canada is 1:24, however the average bull to cow ratio for operations in the current study was 1:21 with the highest ratio at 1:26 and the lowest ratio at 1 bull to 12 cows. More research is needed studying the effect of bull to cow ratios on bull prolificacy, and research is also needed to determine the optimal bull to cow ratio to maximize bull prolificacy.

\subsubsection{Sire age}

\begin{tabular}{cccc}
\hline \multicolumn{4}{l}{ Table 3.4 Chi square analysis evaluating sire age effect on fertility } \\
\hline Ranch/Breeding group & Chi Square & $\mathrm{DF}^{\mathrm{z}}$ & P-value \\
\hline A1 & 260.00 & 8 & $<.01$ \\
A2 & 254.00 & 10 & $<.01$ \\
A3 & 63.00 & 2 & $<.01$ \\
A4 & 140.00 & 6 & $<.01$ \\
B5 & 366.00 & 14 & $<.01$ \\
C6 & 196.00 & 14 & $<.01$ \\
\hline
\end{tabular}

${ }^{\mathrm{D}} \overline{\mathrm{DF}}=$ degrees of freedom.

Sire age had an effect $(\mathrm{P}<0.01)$ on the bull's ability to sire calves (Table 3.4$)$. Sire age ranged from $1 \mathrm{yr}$ of age to $5 \mathrm{yr}$ of age with an average age of $2.64 \mathrm{yr}( \pm 1.27 \mathrm{yr})$. Sires were divided into different age categories for comparison of yearling bulls, 2-yr old bulls, or mature ( $>2$ yr) bulls. Total number of sires evaluated in this study included seven yearling bulls, 14, 2yr-old bulls and 18 mature bulls.

Blocky et al. (1979a) was able to demonstrate that the older, larger bulls that had been on a farm or operation for a longer period of time tended to be the dominant bulls in the group, this 
was shown to correlate with sexual activity as well as number of calves sired (Dzuik 1996). In the same study, Blocky et al. (1979a) found that a group of bulls that were all young bulls (2 yr old) impregnated more females than a group of mixed age bulls. In the current study, bulls in breeding group D7 were all mature bulls but sired a significantly different $(\mathrm{P}>0.05)$ number of calves (Table 3.4). This is inconsistent to the work by Blockey et al. (1979a). Many other factors related to pasture size, the amount of time a bull has been on a farm, and serving capacity (Blockey 1979b) have all been shown to influence the bull libido so bull age alone should not be used as the only predictor of the number of calves a bull will sire. More work is needed into the area of mixed age bull groups vs. same age bull groups and the subsequent effects on fertility.

Because many of the factors associated with poor prolificacy rates in young bulls; such as reduced semen quality and quantity, lower libido, and reduced social dominance have been shown to improve with age, it is suggested that producers not assume a young bull's initial performance in the first breeding season is indicative of future performance (Blocky 1979; Stalhammar et al. 1989; Carpenter et al.1992). This would suggest that the technology of DNA parentage testing should not be used as a culling mechanism for young bulls as performance as a yearling or two-year old may not be a good indicator of future bull performance.

The greatest variation in BPI was observed among the mature bulls (Figure 3.1) with a standard deviation (SD) of 0.72 compared to a SD of 0.53 for 2-yr old bulls and an SD of 0.43 for yearling bulls. However, the older bulls had the highest BPI index with an average of 1.24 compared to 0.74 for the 2-yr old bulls and 0.65 for yearling bulls (Figure 3.1). 


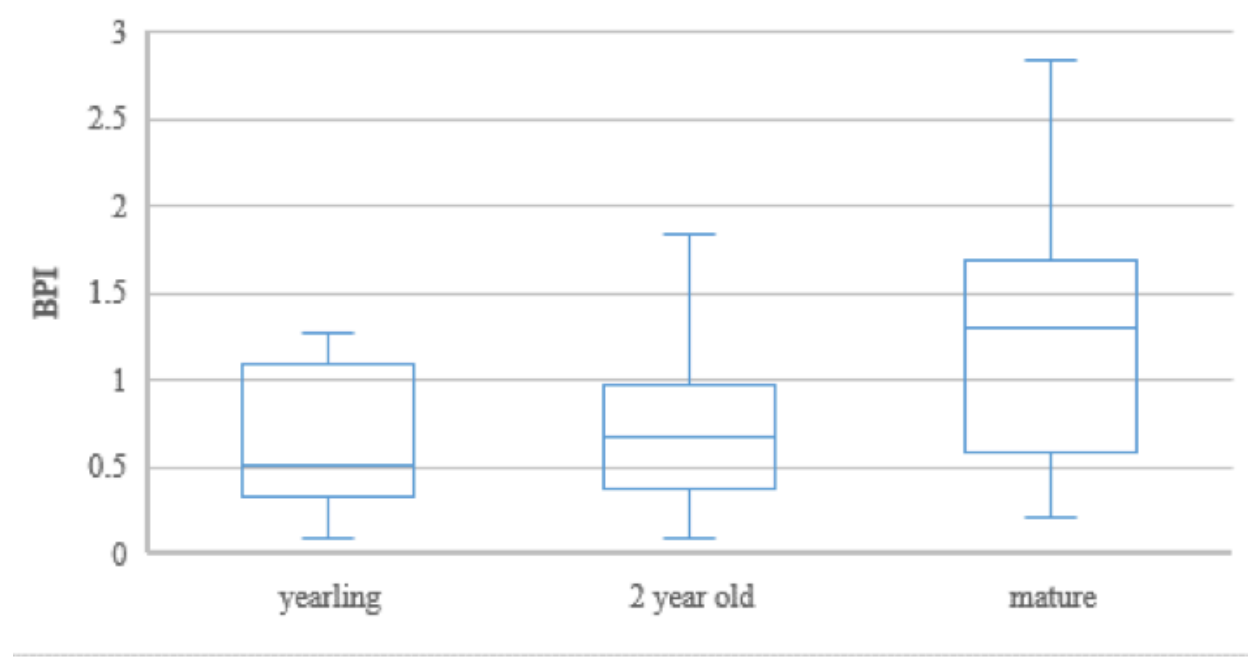

Figure 3.1 Comparison of BPI for yearling, 2-yr-old, and mature bulls

It is important to note that although mature bulls tended to be more prolific in each breeding group, there was one breeding group (A1) where the yearling and 2-yr-old bulls sired the majority of the calves. Body weights (BW) were not collected on bulls in the breeding groups, so it couldn't be determined if BW played a role or not in younger bulls siring more calves in group A1 compared to older bulls. Although one of the breeding groups in the current study had more prolific young bulls, on average mature bulls tend to be more prolific (Figure 3.1). Previous research has also shown that age is directly correlated with semen quality and quantity (Stalhammar et al. 1989). Comparing these results to the current study, this may suggest that the young bulls in each breeding group may have sired fewer calves due to reduced semen quality. Yearling bulls often have a higher incident of abnormal sperm morphology most often in the form of proximal cytoplasmic droplets (Carroll et al. 1963; Barth and Oko 1981; Johnson et al. 1998; Amann et al. 2000 It is well documented that morphological defects in sperm can result 
in reduced rates of fertilization and embryonic development (Wiltbank and Parrish 1986; Barth 1989; Zamboni 1992). It is also known that the incidence of proximal droplets declines as bulls grow older (Barth and Oko 1981; Amann et al. 2000). The presence of a high number of proximal droplets in yearling bull is considered to be a result of abnormal spermatogenesis associated with immaturity (Amann et al. 2000), but can also be a sign of abnormal spermatogenesis due to epididymal function (Johnson et al. 1998) although this is usually not diagnosed until the bull is older (Thundathil et al. 2001). Lunstra and Echternkamp (1982) showed that from puberty to 6 wk post puberty, an increase in normal head morphology and motility as well as a decrease in percentage spermatozoa with proximal cytoplasmic droplets was observed in bull semen. All but 3 bulls (young and old) in the current study had passed the BSE before being turned out to the breeding pasture so the above mentioned sprematological defects would most likely not have played a role in bull prolificacy. This suggests that the low prolificacy rates of younger bulls may be due to social dominance or reduced libido, although neither of these theories were tested.

Previous research has shown that younger bulls can have poor performance in a serving capacity test, which suggests that younger bulls may have a lower libido when compared to older more mature bulls (Carpenter et al. 1992). In a review of age effects on bull fertility, Petherick (2005) suggested that libido and serving capacity doesn't necessarily improve with age, but instead, improves as an effect of sexual experience as the bull ages and has the opportunity to service more cows. 


\subsubsection{Spermatological factors}

Numerous spermatological factors related to sperm motility and morphology are evaluated during the BSE examination before bulls are turned out to breed cows. However, in the current study, only percent normal sperm morphological data was collected on all ranches and therefore was the only factor analyzed.

\subsubsection{Percent normal sperm}

In the current study, there was bull to bull variation in percent normal sperm but all animals were required to pass the BSE before being included in the study. There were 3 bulls in breeding group $\mathrm{C}$ that were mistakenly added to the pasture (one neighbor bull and 2 yearling bulls) that did not have a BSE conducted. Bulls that were used in the current study had a minimum of $70 \%$, maximum of $92 \%$ and mean of $83.7 \%$ normal sperm (Table 3.5 ). The standard deviation for BSE results across all bulls was 5.9 percent.

Table 3.5 Descriptive statistics for percent normal sperm per breeding group compared to average BPI per breeding group

\begin{tabular}{ccccc}
\hline & \multicolumn{2}{c}{ Percent normal sperm per breeding } & \\
Ranch/breeding group & Average & Max & Min & Range of BPI \\
\cline { 2 - 4 } A1 & 83.6 & 86 & 79 & $0.33-1.69$ \\
A2 & 81.3 & 92 & 72 & $0.23-2.48$ \\
A3 & 85 & 89 & 79 & $0.64-1.32$ \\
A4 & 84.8 & 91 & 76 & $0.69-1.37$ \\
B5 & 85.3 & 92 & 78 & $0.21-1.90$ \\
C6 & 81.5 & 88 & 70 & $0.08-2.83$ \\
D7 & 85.3 & 92 & 73 & $0.60-1.29$ \\
\hline
\end{tabular}

$\mathrm{z} 3$ of 9 bulls in breeding group C6 were not scored for percent normal sperm 
Holroyd et al. (2002) observed a correlation between percent normal sperm and number of calves sired by individual bulls $(\mathrm{P}<0.01)$ in two out of the three breeds of bulls. In the study by Holroyd et al. (2002) only Bos indicus breeds were used which may have contributed to some of the difference observed between the two studies.

A more likely reason for the differences is that the bulls used in the study by Holroyd et al. (2002) had a much larger variation in percent normal sperm (10-92\%), since bulls were not required to meet minimum thresholds for percent normal sperm this most likely resulted in the correlation observed between percent normal sperm and bull prolificacy.

In the current study, all bulls were required to meet minimum threshold values for percent normal sperm to be turned out to the breeding pastures. During the BSE, a semen sample from each bull was evaluated for percent normal sperm morphology. The most common sperm defects observed during a BSE are detached heads, distal midpiece reflex, and bent tails (Menon et al. 2011). To pass the BSE exam, sperm collected must have a minimum score of $70 \%$ normal sperm (Chenoweth et al. 1992). Previous research has shown that values below $70 \%$ are shown to affect fertility but values above $70 \%$ do not result in increased fertility (Chenoweth et al. 1992). Since all bulls on the current study were required to pass the BSE and all had a percent normal sperm above $70 \%$ (Table 3.5) it makes sense that no correlation was observed between percent normal sperm and bull prolificacy.

Although a large variation was observed in both BPI and percent normal sperm in the current study, percent normal sperm morphology was found to have a weak correlation $\left(\mathrm{R}^{2}=\right.$ 0.13) with the BPI calculation. This is not unexpected even though previous research has 
indicated that morphological defects in sperm can result in lower fertility rates (Wiltbank and Parrish 1986; Barth, 1989; Zamboni, 1992). In all of the previously mentioned studies sires were used that did not meet the minimum requirement of a percent normal sperm morphology greater than 70 percent. Since all bulls were required to pass the BSE before being turned out in a breeding pasture, the percent normal sperm morphology in the current study was likely not low enough to cause an effect or lower fertility rates.

\subsubsection{Scrotal circumference}

It is well established that SC is highly correlated with fertility and bull age (Bourdon and Brinks 1986; Stalhammar et al. 1989; Coe 1999). In the current study, bull SC ranged from 29 to 46 centimeters. Only one bull had a SC of $29 \mathrm{~cm}$ (one of the yearling bulls that was mistakenly added into the pasture) which is below the required $30 \mathrm{~cm} \mathrm{SC}$ for yearling bulls to pass the breeding soundness examination (Barth 2011). The bull with a SC of $29 \mathrm{~cm}$ also had a BPI of

0.08, further confirming the reason there is a minimum requirement for bulls to pass a BSE exam (Barth 2011). Past research has suggested that once bulls reach a threshold level of SC, selecting bulls for larger SC doesn't seem to affect fertility (Holroyd et al. 2002). In the current study, very little correlation $\left(\mathrm{R}^{2}=0.04\right)$ was found between $\mathrm{SC}$ values and BPI calculations (Figure 3.2), since all but one bull had reached the pre-established benchmark for their age and breed as established by Barth (2013). 


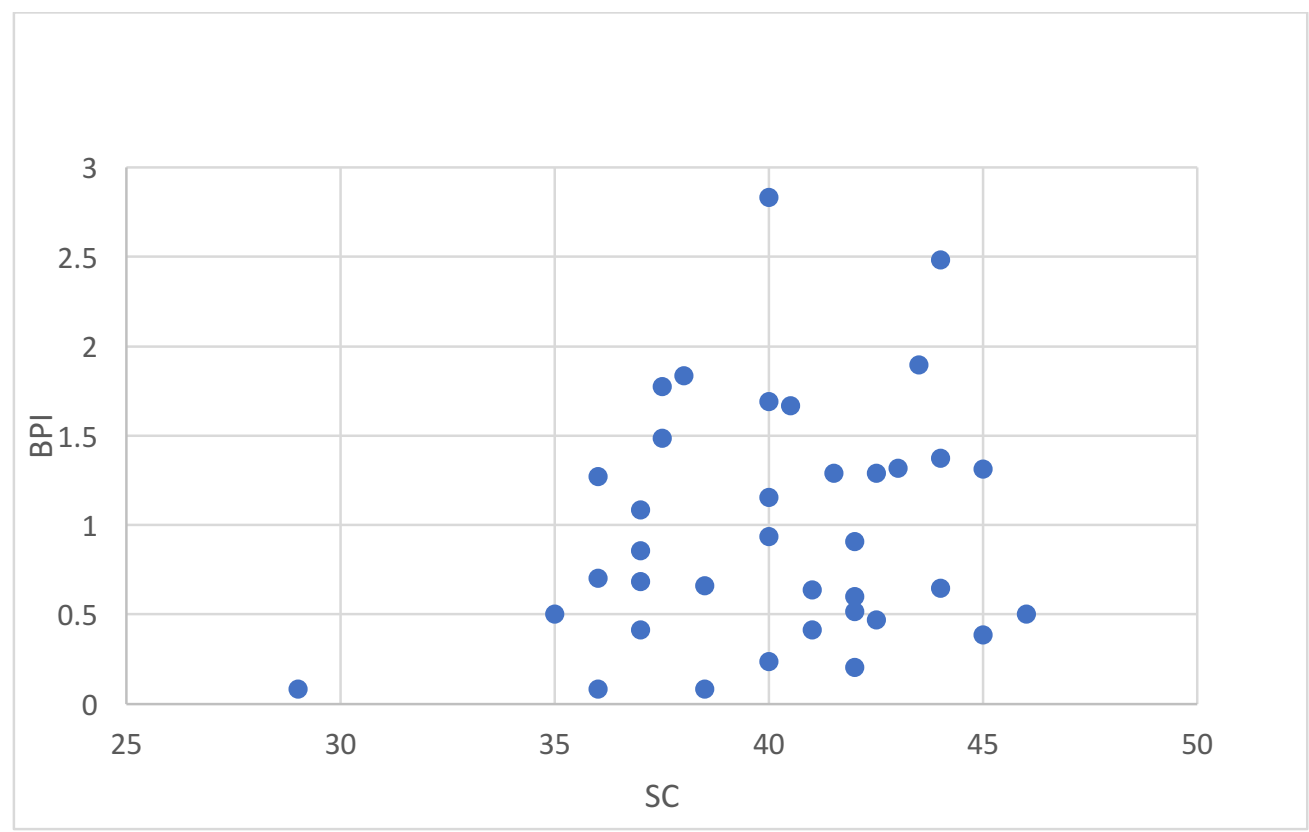

\section{Figure 3.2 Comparison of BPI and SC values of all bulls showing weak correlation $\left(R^{2}=0.04\right)$ between $S C$ and $B P I$}

An association between SC and bull prolificacy has previously been discovered by Van Eenennaam et al. (2014) and Coulter and Kozub (1989). It should be noted that the same correlation was not found in work by Holroyd et al. (2002) possibly due to only studying Bos indicus breeds and that all bulls used in the study had acceptable SC values before being turned out to pasture. In contrast, a study conducted by Coulter and Kozub (1989) included bulls that failed to reach industry benchmarks for scrotal circumference. All the bulls in the study conducted by Van Eenennaam et al. (2014) had a SC greater than the minimum threshold value, yet still a significant correlation $(\mathrm{P}<0.01)$ was observed between $\mathrm{SC}$ and bull prolificacy when one extreme outlier bull was removed from the data set. This contradicts the results of the current study and Holyroyd et al. (2002), in that once bulls pass a minimum threshold value for SC, selecting for higher SC would not affect fertility. Since SC is known to be affected by a number 
of factors including age and breed (Kriese et al. 1991; Barth 2013), the confounding nature of these other traits may have resulted in the differences seen between studies.

In the current study, $\mathrm{SC}$ was also found to be correlated $\left(\mathrm{R}^{2}=0.66\right)$ with age of sire. Although this also raises the question of whether SC or age or a combination of both will affect bull prolificacy suggesting that more research is needed to determine the effect on fertility.

\subsubsection{Number of bulls per pasture}

The number of bulls in a breeding group in the current study varied from three to nine sires (Figure 3.3) although it should be noted in the nine-bull group, only eight were producer bulls and the extra bull was a neighbour bull that invaded the breeding pasture during the breeding season. Figure 3.3 shows that as the number of bulls in a pasture (group) increases so does the variation in BPI among those bulls. There was a direct linear relationship $\left(\mathrm{R}^{2}=0.79\right)$ between number of bulls in a pasture and the standard deviation of the BPI (Figure 3.3). This is consistent with work by Holroyd et al. (2002) in which the authors found that when bulls were mated in groups of eight to 24 there was much greater variation in number of calves sired (ranging between 24 to 94\%) compared to bulls that were in groups of two to seven (ranging 11 to 36\%). Holyroyd et al. (2002) also found that bulls in the larger sire groups also sired on average more calves than those in the smaller groups. This trend was not observed in the current study (Table 3.1) most likely due to the bull:cow ratio differences between studies. In the current study the bulls in the largest breeding groups also had the highest bull:cow ratio (Table 3.3) providing less opportunity for bulls to sire calves as mating activity is known to be dependent on the number of females showing signs of estrus (Rupp et al. 1977). Furthermore, the two breeding 
groups with the lowest number of sires also showed no significant difference $(\mathrm{P}>0.05)$ between number of calves sired by each bull in the group (Table 3.2).

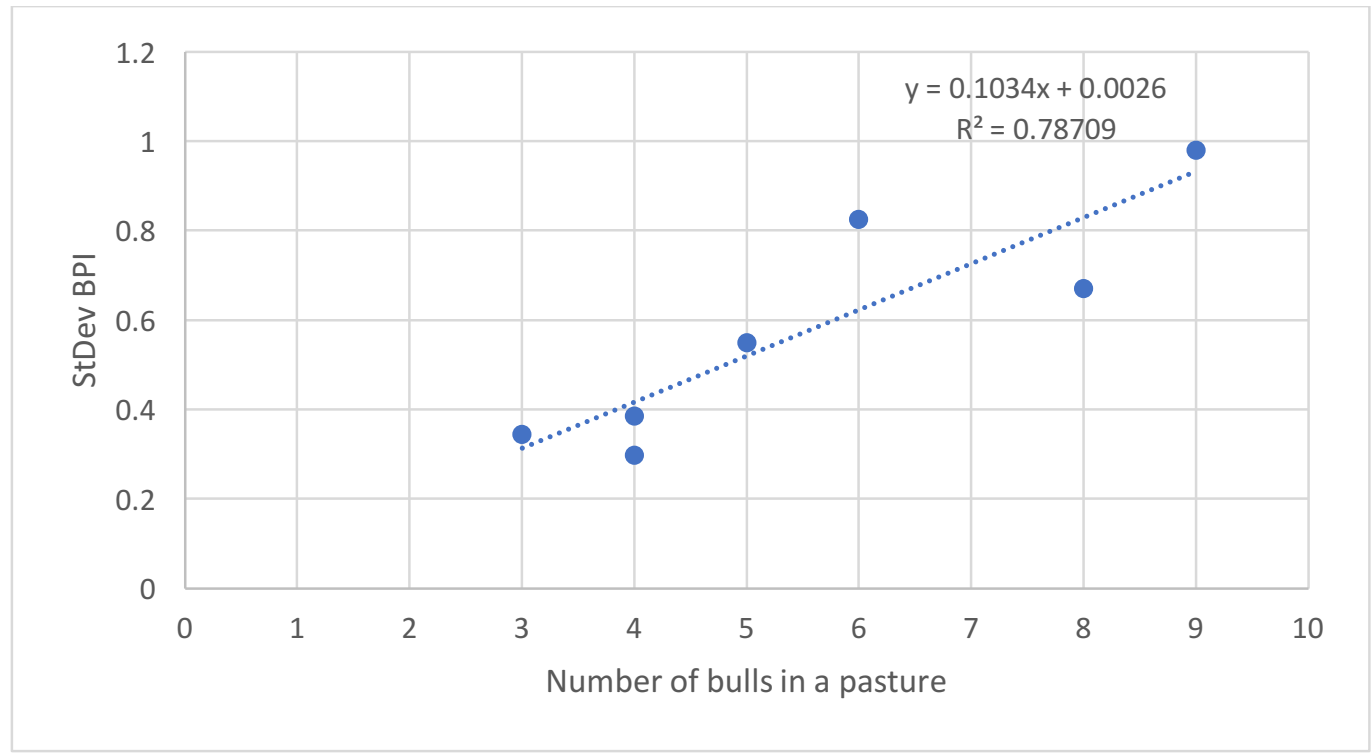

Figure 3.3 Coefficient of determination between number of bulls per breeding group and the standard deviation (SD) of calculated BPI for each group

The relationship between bull number per pasture and SD of the BPI may have been amplified because the group C6 (Table 3.1) with the highest number of bulls, also had a bull to cow ratio less than industry average (1:12). Bulls in this pasture were only expected to sire 12 calves each. In commercial practice, it is expected that bulls be exposed to 24 to 40 cows on average (Fordyce et al. 2002; Hamilton 2006; Larson 2015) it is not unexpected that bulls in this group would have the greatest variation in their bull prolificacy index. 


\subsubsection{No sire match}

DNA parentage results of some breeding groups in the current study had calves that could not be matched to a specific sire. This ranged from 1 to $8 \%$ of total calves sampled among breeding groups at each ranch. Possible reasons for this may have been due to either laboratory quality control or sampling error in the field. This value is lower than $14.6 \%$ of calves that could not be assigned to a sire in work by Van Eenennaam et al. (2007) and the 2.7 to $25.6 \%$ calves whose sire could not be detected observed by Holroyd et al. (2002). The difference between the current study and other studies is most likely due to the number of DNA markers or SNPs used in each laboratory test. Holroyd et al. (2002) used 12 different DNA markers to achieve the above-mentioned results but found that by testing with additional markers they could assign parentage to 92.5 to $100 \%$ of calves in a pasture. Increasing the size of the SNP panel that is used to determine parentage increases the accuracy in which parentage is assigned, but the larger 1000 to 5000 SNP panels, are costlier compared to the 100 to 200 SNP panels (Buchanan et al. 2016). The producer must then decide if the small increase in accuracy justifies the increased cost of the larger SNP panel method.

Samples in this study were also not re-run if results determined that there was more than one possible sire match and a second DNA sample from the dam was required to determine parentage. Doing this additional testing would most likely have resulted in some additional calves being assigned definite paternity. These unidentified sires may also be a result of bulls from other breeding pastures invading the breeding pasture, or even breeding by older bull calves (Van Eenennaam et al. 2014).

The lack of positive sire matches represents not only an economic loss to the producer but also missing information when trying to make sire culling decisions based on parentage 
testing. Although the no matching sire rate is relatively low (1 to $8 \%$ ), improving the sampling technique and resubmitting samples when required could potentially help reduce the number of no sire matches found at testing.

\subsubsection{Alternative sampling methods}

Van Eenennaam et al. (2014) suggested that producers could possibly sample only a subset of the total calf crop and still be able to accurately determine parentage and make culling decisions. This would allow for producers to get samples back from the lab in a shorter turnaround time, and at a lower cost. Van Eenennaam et al (2014) also suggested that by sampling only the calves born in the third week of the calving period, or those born in weeks two, three and four, producers could also get an accurate idea of which bulls were high and low prolificacy. The current study tested calves from one cooperating ranch two different ways. Either all calves born in the third week of calving (calving start date was April 10; three calves born before April 10 were premature and two were born dead), and all calves born in the first 21 days. Calves born in the first $21 \mathrm{~d}$ were chosen because the value of having a large portion of a cow herd calve within the first breeding cycle has been well documented (Burris and Priode 1958; Lesmeister et al. 1973; Sprott 2000). It is recommended across western Canada that producers try to have $65 \%$ of the total cow herd calved within the first $21 \mathrm{~d}$ (first cycle) of the calving period.

Figure 3.4 shows the percentage of the calf crop born each week of the 2015 calving season at Ranch A. Ranch A was the only operation to provide calving dates for all calves that also had all bulls remain in the breeding pasture for the entire breeding period. Week three had the highest percentage of calves born at (26\%) during the calving season. This suggests that it 
may be possible to only test a portion of the calf crop and get results back sooner. Only testing calves born in week three of the calving season is also suggested by Van Eenennaam et al. (2014), and would leave $62 \mathrm{~d}$ (40 d left in the calving season plus $22 \mathrm{~d}$ before resumption of the next breeding season) (Larson et al. 2013) to get lab results back and make culling decisions about the bull battery.

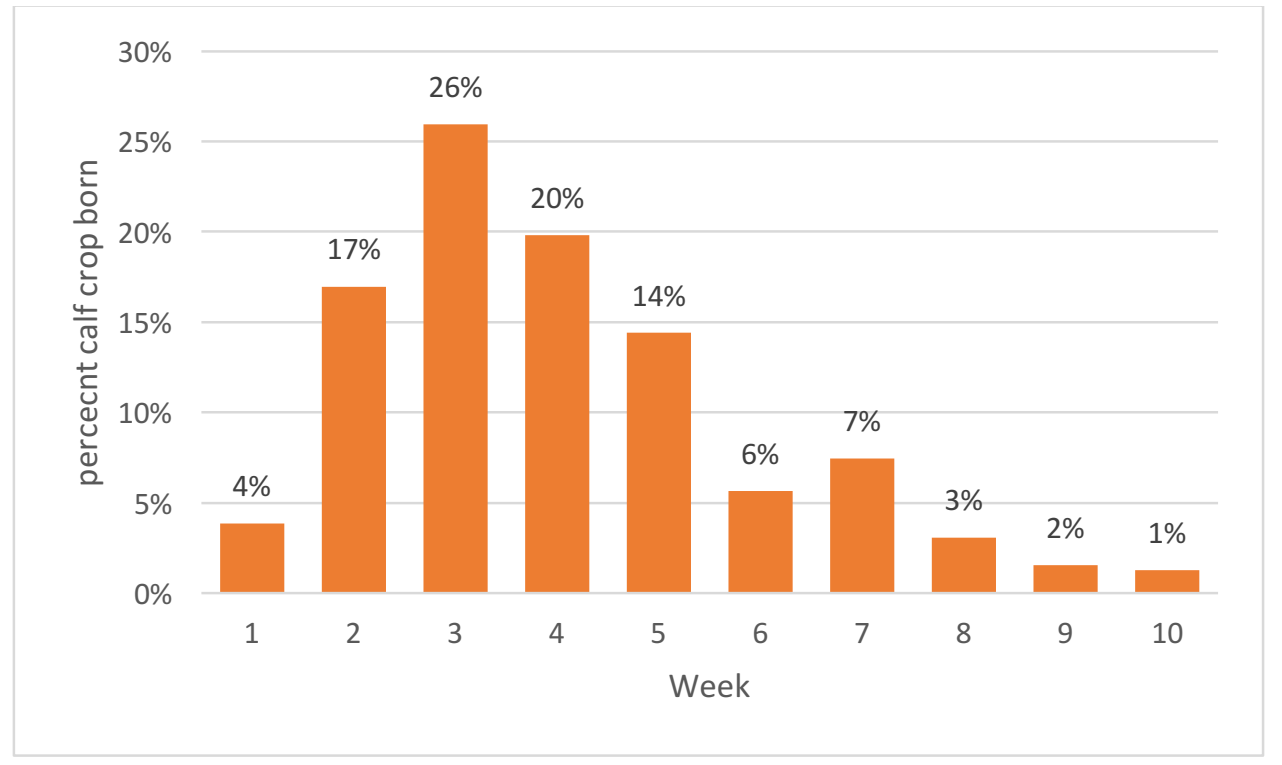

Figure 3.4 Percent of total 2015-born calves born each week at Ranch A

In the current study, only Ranch A provided calving data (Figure 3.4). Calving distribution on Ranch A (Figure 3.4) was similar to what is seen in industry (Larson 2015). Bulls from Ranch A were evaluated two different ways to determine if testing only a portion of the calf crop would give similar results to testing the whole calf crop (Table 3.6). 
Breeding prolificacy indexes for bulls from ranch A were calculated using all of the calves sampled, only calves born in the first $21 \mathrm{~d}$, and only calves born in the third week of calving (Table 3.6)

\section{Table 3.6 Comparison of BPI for calves born in first $21 \mathrm{~d}$, week 3, and total calves born} from Ranch A

\begin{tabular}{cccccc}
\hline $\begin{array}{c}\text { Breeding } \\
\text { group }\end{array}$ & Sire & BPI $^{\mathrm{Z}}$ first $21 \mathrm{~d}$ & BPI week 3 & BPI total & $\begin{array}{c}\text { Total kg } \\
\text { weaned }\end{array}$ \\
\hline 1 & $1108 \mathrm{Y}$ & 0.78 & 0.61 & 0.5 & 2832 \\
1 & $2151 \mathrm{Z}$ & 0.69 & 1.06 & 1.15 & 6905 \\
1 & $256 \mathrm{~A}$ & 0.69 & 0.00 & 1.27 & 7954 \\
1 & $493 \mathrm{Z}$ & 2.59 & 3.03 & 1.69 & 11221 \\
1 & $51 \mathrm{X}$ & 0.26 & 0.30 & 0.39 & 2422 \\
2 & $13 \mathrm{X}$ & 1.36 & 1.88 & 1.31 & 6815 \\
2 & $144 \mathrm{Y}$ & 0.55 & 0.00 & 0.94 & 4294 \\
2 & $1496 \mathrm{Y}$ & 0.55 & 0.19 & 0.47 & 2074 \\
2 & $920 \mathrm{~W}$ & 2.73 & 3.00 & 2.48 & 13268 \\
2 & $549 \mathrm{Z}$ & 0.41 & 0.38 & 0.23 & 1086 \\
2 & $198 \mathrm{~A}$ & 0.41 & 0.19 & 0.52 & 2753 \\
3 & $122 \mathrm{Y}$ & 1.25 & 1.76 & 1.32 & 6729 \\
3 & $212 \mathrm{Z}$ & 1.17 & 0.71 & 0.91 & 4619 \\
3 & $228 \mathrm{Z}$ & 0.58 & 0.53 & 0.64 & 3200 \\
4 & $124 \mathrm{Z}$ & 1.03 & 0.50 & 0.69 & - \\
4 & $401 \mathrm{~A}$ & 0.46 & 0.75 & 0.86 & - \\
4 & $476 \mathrm{~A}$ & 1.26 & 1.75 & 1.09 & - \\
4 & $9050 \mathrm{~W}$ & 1.26 & 1.00 & 1.37 & - \\
& & & & & \\
\hline
\end{tabular}

\footnotetext{
${ }^{\mathrm{z}} \mathrm{BPI}=$ breeding prolificacy index,
}

BPI was also evaluated alongside weaning weight (table 3.6). Hypothetically, even if bulls were high prolificacy, if they were siring most of their progeny after the first $21 \mathrm{~d}$ of the breeding season, these calves would have less opportunity for growth before selling at weaning age and therefore be of lower value to the producer. Lesmeister et al. (1973) showed that calves 
born earlier in the calving season grew faster and weighed more than calves that were born later in the calving season.

This did not appear to be the case for this dataset as every bull that sired the highest total $\mathrm{kg}$ of calf weaned in a pasture also had the highest BPI in that pasture during all three proposed testing times (tale 3.6). Notably, there were some bulls; 256A and 144Y (table 3.6) who had a relatively low BPI when testing only calves born in the first $21 \mathrm{~d}$, as well as sired zero calves in week three. Although both of these bulls were not as prolific as other sires at the beginning of the breeding season, they continued to sire a total $\mathrm{kg}$ of calves weaned that was in the top half of their breeding group. This suggests that even though bulls may be siring bigger calves if they are breeding cows at the beginning of the breeding season, total number of calves sired plays a more important role on total $\mathrm{kg}$ of calf weaned from each bull.

Fleiss' Kappa statistic was calculated to compare bulls with high and low total BPI vs. high and low BPI using only calves born in the first $21 \mathrm{~d}$ on Ranch A. A low BPI was determined to be $<0.05$ with a high BPI being $>=0.05$ (Table 3.7 ). Kappa was calculated to be 0.471 indicating the agreement between the two testing methods is moderate $(\mathrm{p}<0.05)$. In this specific example 15 of the $18(83 \%)$ of bulls were properly classified as high or low prolificacy bulls based on their $21 \mathrm{~d}$ BPI score. Two of the bulls (11\%) were classified wrongly classified as high BPI bulls based on testing only calves born in the first $21 \mathrm{~d}$. One (6\%) bull was wrongly classified as a low BPI bull based on testing only calves born in the first $21 \mathrm{~d}$ (Table 3.7).

Table 3.7 comparing the agreement between the number of bulls classified as high prolificacy $($ BPI $>0.50)$ or low prolificacy $(B P I<0.05)$ of calves born in just the first 21 days VS total calves born on Ranch A

\begin{tabular}{llll}
\hline & High BPI total & Low BPI total & Sum \\
\hline High BPI first 21d & 13 & 1 & 14 \\
Low BPI first 21d & 2 & 2 & 4 \\
Sum & 15 & 3 & 18 \\
\hline
\end{tabular}


Fleiss' Kappa statistic was also calculated to compare bulls with high and low total BPI vs. high and low BPI using only calves born in week three on Ranch A (Table 3.8). Kappa was calculated to be 0.571 and while this is higher than the value calculated for testing all calves born in the first $21 \mathrm{~d}$ of calving, it still indicates the agreement between the two testing methods is moderate $(\mathrm{p}<0.05)$. In this specific example 15 of the 18 bull $(83 \%)$ of bulls were properly classified as high or low prolificacy bulls based on their week three BPI score. Three bulls (17\%) were classified wrongly classified as high BPI bulls based on testing only calves born in week three. No bulls were wrongly classified as a low BPI bull based on testing only calves born in week three (Table 3.8).

Table 3.8 comparing the agreement between the number of bulls classified as high prolificacy (BPI $>0.50)$ or low prolificacy $(\mathrm{BPI}<\mathbf{0 . 0 5})$ of calves born in just week 3 VS total calves born on Ranch $A$

\begin{tabular}{llll}
\hline & High BPI total & Low BPI total & Sum \\
\hline High BPI week 3 & 12 & 0 & 12 \\
Low BPI week 3 & 3 & 3 & 6 \\
Sum & 15 & 3 & 18 \\
& & & \\
\hline
\end{tabular}

By testing only bulls born in the first $21 \mathrm{~d}$ or only calves born in week three, relatively low numbers of bulls were wrongly classified when compared to the BPI results after testing the whole herd; three bulls in each example (Table 3.7; Table 3.8). Since this data only looks at one ranch there may not be enough total sires to result in a high degree of agreement between the two testing methods. Further research is recommended in this area to determine if testing only calves born in the first $21 \mathrm{~d}$ or week three is accurate enough to assume a bull's total prolificacy and make culling decisions. 
Using Ranch A as an example, if they were making culling decisions based on data from week three alone, three bulls that were actually considered high BPI bulls based on total year performance would have been wrongly culled (Table 3.8). If this same ranch were to test all calves born in the first $21 \mathrm{~d}$ of calving to base culling decisions on, 2 bulls would be wrongly culled based on total BPI (Table 3.7 ). The rate of low total BPI bulls that would be allowed to breed in future years based on their calculated BPI for only the first $21 \mathrm{~d}$ or week 3 ( 1 and 0 respectively). This suggests testing only a portion of claves born may be more accurate at identifying high prolificacy sires than low prolificacy sires.

Although a moderate statistical agreement between the tests was found, numerically the number of bulls that disagreed with the final ranking was relatively low. More research is needed into if testing only a portion of the herd is useful to determine overall bull prolificacy, but based on the cost savings it may be a strategy that producers are willing to adapt.

\subsection{CONCLUSION}

Bulls in multi-sire groups were found to sire different number of calves and many factors were found to affect bull prolificacy. This suggests that there is no simple method to fairly evaluate the bull's ability to sire maximum number of calves in a breeding season. However, using DNA parentage testing technology may allow a producer more information to confidently evaluate prolificacy or culling of the sire.

In the current study, age was shown to play a significant role when determining bull prolificacy, with older bulls siring more calves than younger bulls. Since both yearling and twoyr old bulls sired fewer calves compared to mature ( $>$ two yr of age) bulls, a recommendation 
may be to not use primarily DNA parentage testing results as a method to evaluate bulls younger than three yr of age.

A bull prolificacy index (BPI) was developed to compare which bulls are siring more or less than expected number of progeny. The number of bulls in a breeding pasture also influenced the standard deviation of a calculated bull prolificacy index, as the number of bulls in a breeding pasture increased so did the variation in number of calves sired by each bull. No conclusions could be made on the effect of bull:cow ratio on number of calves sired based on a low number of breeding groups. It is assumed that bull:cow ratio also plays a role in number of calves sired by each bull but more research is needed to determine any effect bull:cow ratio has on bull prolificacy.

Both sire age and number of bulls in a breeding pasture influenced the social hierarchy and social dominance of bulls in each group. Suggesting that although bull prolificacy is a moderately repeatable trait, bulls may not sire the same amount of calves year after year but are likely to remain as either high or low prolificacy sires.

Percent normal sperm was not correlated with BPI values and had no net effect on number of calves sired by each bull in this study. Although previous research has shown that percent normal sperm played a role in bull prolificacy, in this study only bulls who had met minimum benchmarks to pass the BSE were used, therefore using only bulls who passed the BSE exam, resulted in percent normal sperm having no effect on bull prolificacy in this study.

There was no correlation between SC and bull prolificacy. As with percent normal sperm, this is most likely due to bulls having to reach benchmarks set for age and breed to pass the BSE evaluation. 
The number of calves without a sire match ranged from one to eight percent of all calves tested. 'No sire match' calves represent a cost with no economic return on investment. Producers may be able to reduce this number by re-submitting calf or dam DNA samples. Submitting additional samples will increase labour costs and may not be worth the effort considering the no sire match numbers were low compared to previous studies.

To reduce the cost of DNA parentage testing previous research has suggested only testing a subset of all calves born. Testing only calves born in the first $21 \mathrm{~d}$ or in week three of the calving season resulted in numerically low number of sires that were wrongly assigned to high or low prolificacy groups. Testing only a subset of calves may provide producers with a chance to decrease cost and the time it takes for samples to be collected. With a relatively small number of sires that were wrongly reassigned this provide producers the chance to determine bull prolificacy without sampling an entire calf crop.

Bulls are known to remain in a herd for less time than cows and are culled at a much higher rate than cows. Because it has been shown that mature bulls are more prolific than younger bulls it is not recommended to cull bulls based on DNA parentage testing before they reach three yr of age. Depending on the age at which bulls are culled on an operation, producers may question the economic advantage of DNA parentage testing progeny to make bull culling decisions.

Finally, multi-year studies are needed to evaluate bull prolificacy in changing sire breeding groups, which is common in commercial practice to evaluate the long-term value of DNA parentage testing and use the results as a tool to cull non-prolific bulls. 


\subsection{ECONOMICS OF DNA PATERNITY TESTING AS A METHOD TO DETERMINE BULL FERTILITY}

\subsection{Introduction}

Recent advances in technology have resulted in SNP testing replacing microsatellite testing for parentage testing. With the change in testing method has come a decrease in the cost of DNA parentage testing. DNA parentage testing is already used extensively in the purebred cow-calf industry and the cost of testing is now affordable for commercial cow-calf producers as well (Van Eenennaam and Drake 2012). In western Canada, parentage testing costs in the range of $\$ 12$ to 20 (plus GST) per head, depending on genetic laboratory used and the number of samples being tested.

Previous research has shown that the number of calves sired by a bull is a moderately repeatable trait (Holroyd et al. 2002). This suggests that results received from paternity testing may be relied on to make culling decisions for non-prolific sires. The primary source of income for a cow-calf producer is the sale of weaned calves, with the price received being influenced by both weight and quality attributes (Carlberg and Hogan, 2013). A herd sire influences a commercial producer's income as the bull must impregnate females and pass on quality genetics to his progeny (DeNise 1999; Garrick and Golden 2009; Van Eenennaam 2012). It is therefore critical that these sires are actually producing offspring (Van Eenennaam and Drake 2012). Integrating DNA parentage testing is one way for commercial cow-calf operations using multisire breeding pastures to verify and evaluate a bull based on progeny and performance of the calves. 
The cost of maintaining a bull battery is substantial and is borne by the breeding females in a herd, with each bull in a breeding group expected to breed similar number of females (Larson 2013). Previous research has shown there is often wide variability in the number of calves sired by each bull in a multi-sire breeding pasture (Van Eenennaam et al, 2007). When the number of cows that a bull actually services is below the expected number (bull:cow ratio), either the other bulls in the breeding group need to make up the shortfall or conception rates will be impacted.

The value of a bull lies not only in the number of calves sired, but also in the market value of those calves (Garrick and Golden 2009). For cow-calf producers, market value is influenced by the weight and quality attributes of the calves weaned (Carlberg and Hogan 2013). However, waiting on weaning weights to make herd sire culling decisions is problematic because the next breeding season has already concluded before the current calf crop is weaned. Culling non-prolific sires prior to the resumption of the next breeding season will require early collection and testing of all bulls and calves using DNA parentage.

Most economically relevant traits are complex meaning multiple genes and the environment are playing a role (Garrick and Golden 2009). Because of this it is difficult to develop a genetic test because many different genes are interacting to produce an outcome (Bongiorni et al. 2012; Abo-Ismail et al. 2014). Therefore, it is of greater economic value to search for a simple trait that is only controlled by one gene and develop genetic tests to detect that trait (Dekkers 2004). Because of the simple genetic markers used, DNA parentage testing is a prime candidate for an economically viable DNA test that can be used as a selection tool.

For producers who retain ownership of their calves until slaughter, carcass grading results can aid in sire selection and culling. Research by Van Eenennaam et al. (2008), has shown that 
average steer carcass values from 19 different sires varied by as much as $\$ 160$ with $26 \%$ (5 out of 19) of the sires providing half of the income generated. The majority of producers in western Canada market their calves at or shortly after weaning (Larson 2015), which allows limited ability to obtain carcass performance data on calves not retained. A lack of vertical coordination in the beef supply chain with data and profits not being shared, means downstream impacts of sire selection are often overlooked by producers.

There is also the potential for downstream sectors of the beef industry to benefit from DNA parentage testing. Sharing sire, dam, and production records for an animal from birth to slaughter has value beyond the farm gate (Unterschultz, 2000). Improved expected progeny differences and rate of genetic gain could be possible, especially for hard to measure, economically relevant traits (Van Eenennaam and Drake 2012). The use of genetic information to make management decisions has been adopted much sooner in other industries such as dairy, pork, and poultry because of vertical integration (Van Eenennaam and Drake 2012). In the beef industry, however, there is a lack of vertical integration in the supply chain which means that data and profits are often not shared between sectors (Van Eenennaam and Drake 2012). A cost incurred by the cow-calf producer may generate downstream benefits and value not shared with the primary (cow-calf) producer. For this reason, the focus of this economic evaluation chapter is the costs and benefits that accrue to the commercial cow-calf producer from using DNA parentage testing in multi-sire breeding groups (pastures).

\subsection{Materials and Methods}

Economic analysis of DNA parentage testing incorporated varying levels of implementation and scenarios. Economic models were built to determine the value of parentage 
testing to commercial cow-calf producers. Economic models were developed using both example data based on relevant industry assumptions and data collected from two of the cooperating ranches in the current study. Only data from Ranch D and Ranch A were used as these two operations provided calving date, dam identification, calf birth weight and wean weight in the study. Following approaches by Larson (2010) and Johnson and Jones (2004) relevant assumptions and industry data on bull purchase price, bull:cow ratio, years of use, cull value, feed and yardage costs and risk of loss were used to illustrate the cost of maintaining herd sires for natural service breeding.

A cost and benefit comparison of varying levels of implementation of DNA parentage testing - all calves, only calves born in week 3 , only calves born in first $21 \mathrm{~d}$ - was conducted to determine if a producer could reduce costs by parentage testing a portion of their calves, and still correctly identify low and high prolificacy sires.

A number of variables must be considered when calculating the annual cost of maintaining a herd bull and include purchase price, estimated cull value, feed, grazing, and herd health costs. Years of use, risk of loss and injury, and the number of females serviced were also included in the calculations. Following the approaches used by Johnson and Jones (2004) and, Larson (2010) the annual cost of maintaining a bull is calculated as:

\title{
Equation 4.1 Annual bull cost
}

\author{
Annual Bull Cost $=\frac{(\text { Purch }- \text { Cull })}{\text { YearsUsed }}+$ FeedC + YardageC + HealthC + RiskLoss $\%$ \\ Where: \\ Purch is the purchase price of the bull
}


Cull is the estimated market value of the bull at time of culling

YearsUsed is the number of years the bull will be used for breeding

FeedC is the annual cost and/or market value for feed, bedding, pasture, mineral and salt

YardageC is the annual cost for equipment, infrastructure and labour related to feeding the bull

HealthC is the annual cost for semen testing and vaccinations

RiskLoss $\%$ is the percentage chance that the bull will need to be replaced because of death or injury; percent $\mathrm{x}$ purchase price

To determine the cost per female service, the annual bull costs would be divided by the number of females the bull was expected to breed, and is represented by:

\section{Equation 4.2 Natural service cost per female}

$$
\text { Natural Service Cost per Female }=\frac{\text { Annual Bull Costs }}{\frac{\text { CowsExposed }}{\text { TotalBulls }}}
$$

Where:

Annual Bull Cost is the annual cost of maintaining a bull as determined in Eq \#

CowsExposed is the number of females in the breeding field

TotalBulls is the number of bulls in the breeding field 
To determine the cost per weaned calf, the Natural Service Cost per Female needs to be divided by the wean percentage or calving rate, as follows:

\section{Equation 4.3 Bull cost per weaned calf}

$$
\text { Bull Cost per Weaned Calf }=\frac{\text { Natural Service Cost per Female }}{\frac{\text { CowsExposed }}{\text { CalvesWeaned }}}
$$

Where:
Natural Service Cost per Female
as calculated in Equation 4.2
CowsExposed
is the number of females in the breeding field
CalvesWeaned is the number of calves weaned

For purchase price (Purch), the average sale price for Angus bulls in Canada in 2015 was used (\$6,797.21; Canadian Angus Association, 2016). Johnson and Jones (2004) used the average sale price of Angus bulls as reported by the American Angus Association. Justification was that the Angus breed accounts for $68 \%$ of the national herd (Canfax, 2009), making it a suitable representation for the national average selling price for herd sires. The cull value (Cull) was representative of the four yr (2012-2015) average cull price was $\$ 106.73$ per cwt (Canfax, 2015). The estimated average bull weight was $910 \mathrm{~kg}$ for a cull value of $\$ 2,134.60$. The years of use (YearsUsed) was four which is in line with the assumptions by Johnson and Jones (2004), Larson (2010) ${ }^{1}$. In the United States the average age bulls are culled is at 5.7 (Ramsay et al. 2016) which equates to five yr of use if the bull started breeding as a yearling or four yr if the bull started breeding as a two yr old. A Canadian study looking at 2466 bulls in western Canada found that $80 \%$ of bulls were four years-old or less. Subtracting Cull from Purch and dividing by

\footnotetext{
${ }^{1}$ WBDC production records show the average age of herd sires from 2007-2016 to be 4 years (3 years of use).
} 
Years Used calculates the annual bull depreciation or decline in value of the bull, which is calculated to be $\$ 1165.65$ as shown in equation 4.4 .

\section{Equation 4.4 Annual bull depreciation}

$$
\begin{aligned}
& \text { Annual Bull Depreciation }=\frac{\text { Purch-Cull }}{\text { Years Used }} \\
& \qquad \begin{array}{l}
\text { Annual Bull Depreciation }=\frac{6,797.21-2,134.60}{4} \\
\text { Annual Bull Depreciation }=\$ 1165.65
\end{array}
\end{aligned}
$$

In the estimation of feed, bedding, grazing and mineral and salt expenses (FeedC) an example ration and market value for each feedstuff was used. Following the recommended rations from the Alberta Beef Manual, assumes the bulls have a $180 \mathrm{~d}$ winter feeding period (November 1 through April 30) and are provided with $16 \mathrm{~kg}(35 \mathrm{lb})$ of good quality hay ad libitum and $2.7 \mathrm{~kg}(6 \mathrm{lb})$ of rolled barley per head per day. The four yr average market values (2012-2015) reported by the Alberta Farm Input Price Survey is $\$ 0.09$ per kg for hay and $\$ 0.19$ per kg for barley. Bedding straw is estimated to cost $\$ 25$ per bull based on Manitoba Agriculture's Cost of Production estimate of one tonne bedding straw per bull per year and an estimated market value of $\$ 25$ per tonne. ${ }^{2}$ Salt and mineral is estimated to cost $\$ 0.10$ per head per day based on previous WBDC study calculations. The bulls are assumed to graze for $185 \mathrm{~d}$ and the market value of grazing is estimated at $\$ 1.00$ per head per $\mathrm{d}$ based on the 2012

\footnotetext{
${ }^{2}$ WBDC paid $\$ 25$ per bale for straw in $2014 / 15$.
} 
Saskatchewan Private Lease Rate Survey and the 2015 Alberta Pastureland Lease and Rental Survey.

The value for YardageC is $\$ 1.17$ per head per $d$ and is based on the yardage costs in the 2012 Saskatchewan Cost of Production findings (Larson 2013) multiplied by 180 days. To determine HealthC, pricing for vaccines to treat for bovine viral diarrhea, blackleg, footrot and parasites were obtained from the Watrous Animal Hospital, Watrous, Saskatchewan. Additionally, the cost of the BSE (\$75.00 per head) is pricing from Watrous Animal Hospital.

The RiskLoss\% is based on the chance of the bull getting injured or dying and needing to be replaced is set at $10 \%$ of the bull purchase price based on values used by Johnson and Jones (2004) CowsExposed is set at 25 which is the average bull:cow ratio among Western Canadian Cow-Calf Survey respondents was one bull per 25 females (Larson 2015) which is in line with traditional recommendations of 25 to 30 females per bull (Alberta Agriculture and Forestry 2008). A tabular summary of the assumptions can be found in Appendix B.

\subsection{Results and Discussion}

\subsubsection{Cost of maintaining a herd sire}

Using the assumptions and values listed in Table 4.1, the cost to maintain a herd sire was estimated to be $\$ 2,755.87$ or $\$ 110.23$ per 25 cows serviced. 
Table 4.1 Annual costs of maintaining a herd sire, \$/head

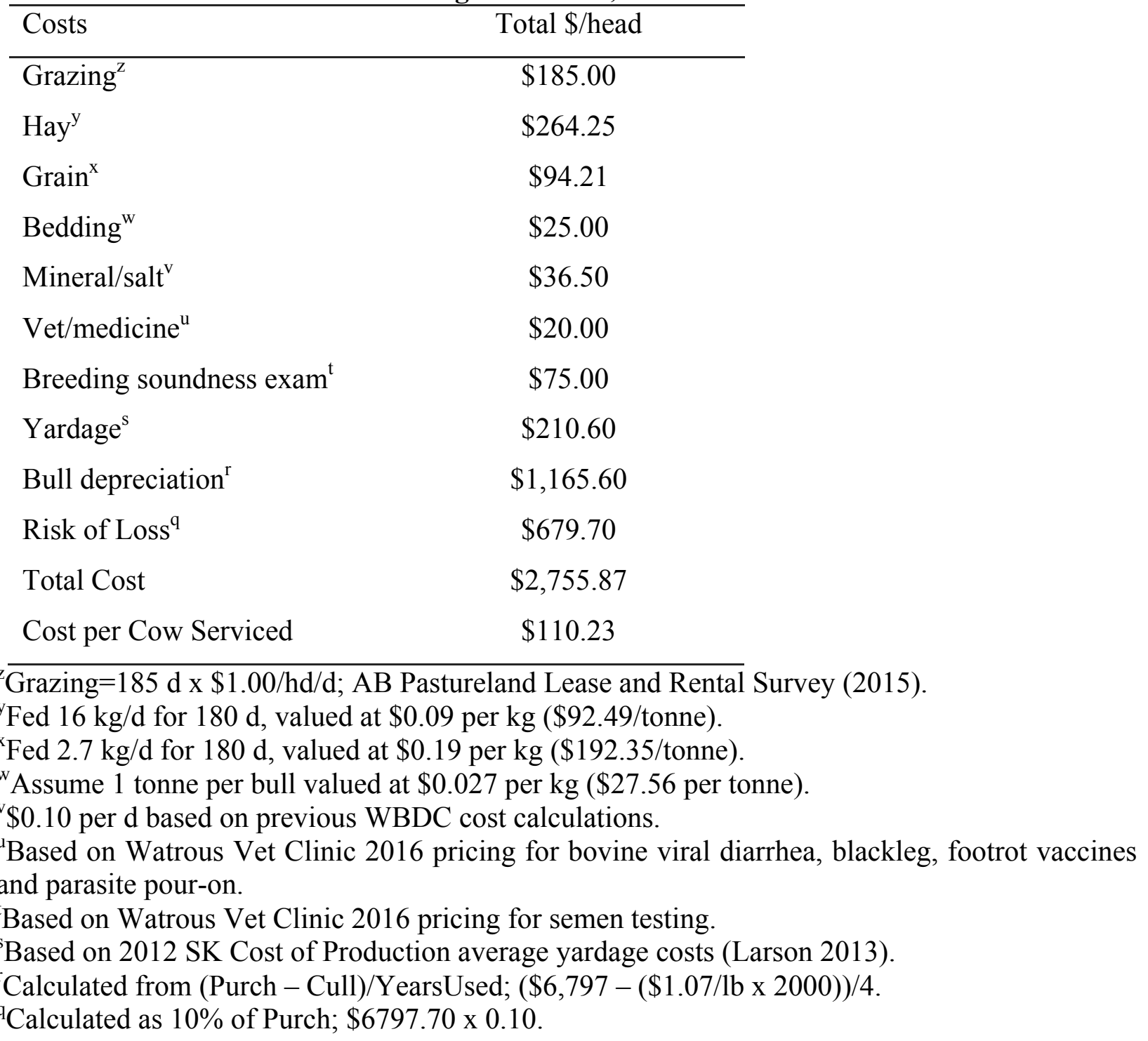

If the number of females serviced is 35 per yr, the cost drops to $\$ 78.74$ per cow. If the bull only breeds two cows, the cost per cow increases substantially to $\$ 1285.43$ per cow (Figure 4.1) With the assumptions used for this example, if the bull services fewer than 25 cows, it may be more economical for the producer to use artificial insemination (AI) which is estimated to cost \$94 to \$125 per female and allows a producer to access proven, top genetics (Lardner et al. 
2015). Figure 4.1 shows that as the number of females serviced decreases so does the cost of female serviced, according to this example if a bull is siring less than 23 calves it is cheaper for the producer to use fixed time AI than to maintain the bull. The rule of thumb that each bull in a multi-sure breeding field breeds an equal number of females has been shown to be inaccurate through DNA parentage testing (Van Eenennaam et al. 2007). If a producer is able to increase the average number of calves sired by bulls in a pasture (increasing from 25 to 30 calves sired per bull) means there is potential for economic gain. The cost to maintain the sire is spread out over more years and there is potential to reduce the total number of bulls on the operation.

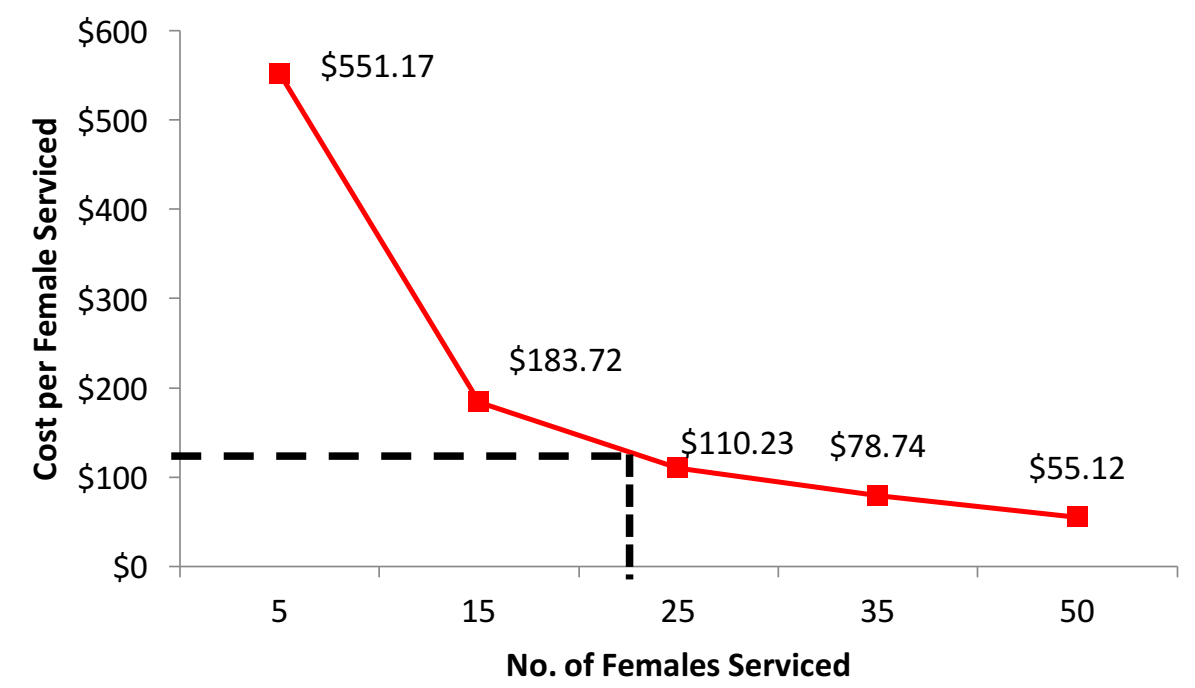

Figure 4.1 Change in cost per serviced female compared to cost of AI at $\$ 125$ per head.

Previous work has shown there is wide variation in the number of progeny that are sired per bull in multi-sire breeding pastures. (Holroyd et al. 2002; Van Eenennaam et al. 2014). Depending on how producers manage their data, and the timeliness in which the data can be 
collected, evaluated, and put to use on the farm, there may be value in identifying which of the sires are meeting, exceeding, or breeding less females than expected.

\subsubsection{Costs associated with parentage testing}

\subsubsection{Lab costs and herd size}

The cost of parentage testing in western Canada varies from $\$ 12$ to $\$ 20$ plus GST per head depending on the laboratory and number of samples being tested. A herd size of 300 cows (includes 14 breeding bulls based on a 25:1 ratio plus two alternates) would cost between $\$ 3700$ and $\$ 6150$ per yr (assuming 93\% of cows had a calf and bulls were tested each yr).

\subsubsection{Other costs}

In addition to laboratory costs, there are costs associated with animal identification, labour to collect and submit DNA samples and the time, skill, and potentially herd management software to help the producer interpreting the data and determine how to best use the information on their operation. The labour and effort varies depending on whether DNA samples are collected while animals are being handled for other purposes or solely to collect DNA samples. These costs for time, skill, and software have not been incorporated into the analysis due to the variability of herd management software programs and skill of the person interpreting the data.

\subsubsection{Benefits of DNA parentage testing}

As mentioned previously, there are many ways in which producers can benefit from DNA parentage testing and subsequent incorporation of the results for informed management decision 
making. A limitation of this study is that it only followed one breeding and calving season on four different operations. The benefits of identifying (and culling) under-performing sires needs to extend beyond one year. Given this limitation, analysis focused on the cost of varying levels of testing - all calves, calves born in week three, calves born in first $21 \mathrm{~d}$ - and the ability to still identify the top and bottom performing sires (Table 3.6).

\subsubsection{Increasing weaned calf weight}

Given that the revenue for commercial cow-calf producers comes primarily from the sale of weaned calves (Ramsey et al. 2005), a potential outcome from parentage testing would be to increase the total number of $\mathrm{kg}$ weaned. Van Eenennaam et al. (2014) did report that bulls who sired the most calves also tended to have the highest total $\mathrm{kg}$ of calves weaned.

Beef producers who DNA parentage tested their calf crop and also capture weaning weights could calculate total $\mathrm{kg}$ of calf weaned for each sire. This information could then be used to identify sires with the lowest total $\mathrm{kg}$ weaned, and culling these sires could lead to an increase in overall $\mathrm{kg}$ weaned. If sires responsible for the lower WW progeny were removed and weaning weights increased $0.45 \mathrm{~kg}$ on average, the increased advantage for a 300 -head cow herd $(95 \%$ calf crop) would be $\$ 1189$ (based on $\$ 4.17 / \mathrm{kg}$; Canfax 2015). In that same herd, the cost of parentage testing at $\$ 12$ a test would cost $\$ 3,420$ as this is based on $0.91 \mathrm{~kg}$ multiplied by $\$ 208.69$ per cwt (5 yr fall-run price for $250 \mathrm{~kg}$ steer calves; Canfax 2015) multiplied by 285 calves. For DNA parentage testing to pay off using only an increase in weaning weights, herd weaning weights would have to increase by $2.61 \mathrm{~kg}$ every year the calves were tested. This means that increasing weaning weight alone should not be the main focus when using DNA parentage testing to make culling decisions. 


\subsubsection{Removal of non-prolific sires}

Another potential benefit of parentage testing could be the cost savings from removing a non-prolific sire. As stated above, the annual cost of maintaining a herd sire can exceed $\$ 2,700$ (Table 4.1). If the bull is siring a low number of calves this cost is then spread out over less calves increasing the cost per calf sired (Figure 4.1). Since DNA testing all the calves and sires in the previous scenario costs $\$ 3420$, the cost of culling only one bull won't necessarily result in a break-even cost. It is suggested mature bull prolificacy is a moderately repeatable trait (Holroyd et al. 2002), meaning performance of mature bulls after only one yr of DNA parentage testing can be relied on to cull non-prolific sires. If a bull is found to be a low prolificacy sire as a young, mature bull (ex three yr old) culling this bull would not only result in the $\$ 2000$ savings to maintain the bull that year but also in the following years. For example, if a three-yr-old bull was found to have a low number of calves and was expected to breed for three additional years the savings back to the producer would be $\$ 2,580$. It should be noted that although there is a savings to the producer to cull the bull, in most situations the producer would choose to replace the culled bull with another bull and the cost of replacement is not included in the previous calculation.

At each of the cooperating ranches there were bulls that sired more or fewer calves than what were expected (Table 3.1). To allow for comparison between bulls from pastures with different bull: cow ratios, a BPI was calculated for each of the bulls in the study. This number compares how many calves a bull was expected to sire compared to the number females they were expected to breed. There was a statistical difference $(\mathrm{P}<0.05)$ in the number of calves sired by each bull in a pasture (Table 3.2). Efforts were made to obtain bull purchase price for each 
cooperating ranch, however other costs associated with feed, pasture, animal health and yardage were not collected. Purchase prices were obtained for 19 of the 37 bulls (Table 4.2 ) or $51 \%$ of the sires in the current study. All data collected on bull purchase price was collected from one operation.

\begin{tabular}{cc}
\hline Table 4.2 Purchase price for 19 bulls used in the current study \\
\hline Bull number & Purchase Price \\
\hline $122 \mathrm{Y}$ & 3300 \\
$124 \mathrm{Z}$ & 2000 \\
$132 \mathrm{~B}$ & 5450 \\
$144 \mathrm{Y}$ & 3300 \\
$1496 \mathrm{Y}$ & 3000 \\
$175 \mathrm{~B}$ & 5950 \\
$17 \mathrm{~A}$ & 3800 \\
$198 \mathrm{~A}$ & 3800 \\
$212 \mathrm{Z}$ & 3000 \\
$2151 \mathrm{Z}$ & 3200 \\
$21 \mathrm{~A}$ & 3550 \\
$256 \mathrm{~A}$ & 3550 \\
$300 \mathrm{~B}$ & 5450 \\
$493 \mathrm{Z}$ & 2000 \\
$549 \mathrm{Z}$ & 3250 \\
$644 \mathrm{~B}$ & 6750 \\
$920 \mathrm{~W}$ & 2700 \\
$94 \mathrm{~B}$ & 5950 \\
$97 \mathrm{~B}$ & 5450 \\
\hline
\end{tabular}

The average purchase price of the bulls was $\$ 3,971$, and ranged from $\$ 2,700$ to $\$ 6,750$ with $\$ 1,410.60$ as the standard of deviation. This is lower than the total dollar value used to calculate bull depreciation value for Table 4.1 but since this only represented costs from one beef operation, not an industry average, it was not used. 
The average bull:cow ratio was 25:1, however, the average number of calves sired by the bulls in the current study was 19.5 , ranging from one to 53 calves. The calculated annual cost of maintain a herd sire is $\$ 2755.87$ (Table 4.1 ), if that bull is only siring 1 calf that calf bares the entire cost of $\$ 2755.87$, however if the bull sires 20 calves the yearly cost of the bull drops to $\$ 137.79$ per calf, and if that bull is siring 40 calves the yearly cost of the bull reduces further to $\$ 68.90$ per calf.

The biggest problem associated with using parentage testing to remove non-prolific sires is that an individual is not aware of the non-prolific sire until after DNA test results are complete and returned to the producer. This implies that the producer will not know if DNA parentage testing will be of any economic value to the operation until they have adopted the technology over at least two breeding seasons.

\subsubsection{Using parentage test results to reduce dystocia}

If there are incidences of calf deaths as a result of difficult births (dystocia), a producer could use DNA parentage testing to determine if one bull is responsible and if so, which bull is causing the difficult births. It is reasonable to assume that if producers are seeing a larger percentage of dystocia after bringing new bulls into the herd, the new bulls may be at fault (Laster et al. 1973; Meijering 1984). In some cases, the cow factors such as body weight or cow nutrition may also be playing a role in dystocia rates but due to the low cost associated with only testing the calves that had a difficult birth it is probably worth it for a producer to test for a dystocia causing bull. Producers may be able to attribute multiple cases of dystocia and still births to one or two bulls and cull them to prevent future problems. 
Bellows et al. (1987) showed that of all calves that were lost at or around the time of calving, $51 \%$ of those calves had a difficult birth. If the incidence of calf death arising from difficult births is only $1 \%$ on a 300 -cow operation, testing for the sire of only calves who experienced the difficult births (three calves $\mathrm{x} \$ 12$ and 14 bulls $\mathrm{x} \$ 12$ ) is easily justified by the potential market value of those calves at weaning (three calves x $250 \mathrm{~kg}$ x $\$ 3.75 / \mathrm{kg}=\$ 2812.50$ ). Theoretically then for $\$ 200$, a producer can identify which bull(s) are responsible for dystocia in the herd. Although it is hard to assign a dollar value there would also be economic benefit from preventing dystocia which could lead to increased calf weaning weights, increased cow performance, and a higher rebreeding rate of cows (Meijering 1984).

\subsubsection{Other benefits}

There is potential for producers to use sire verification to improve selection criteria for replacement heifers, to reduce inbreeding in their herd, or to increase factors such as herd health or docility. All of these factors would potentially provide an economic value to the producer but were not measured in this study. Therefore, future research is recommended into the long-term herd effects of parentage testing.

\subsubsection{Value in DNA parentage testing}

Few of the previously discussed reasons for parentage testing make economic sense by themselves, but when combining the benefits that can accrue as a result of parentage testing it may become more appealing to producers. Supporting production records (calf birth date, birth weight, WW, dystocia at birth) along with an adequate on farm calf identification system will increase the ability to generate value from parentage testing. In 2007, Amer et al. (2007) showed 
that at current rates of change, if $10 \mathrm{yr}$ of genetic improvement were made over $20 \mathrm{yr}$ it would be an increase in value of 4.9 million British pounds (8.1 million Canadian Dollars) to the United Kingdom (UK) beef industry. Although there are major differences in the UK and Canadian beef industries it is reasonable to expect that genetic improvement would result in economic gains for the Canadian beef industry. In their report Amer et al. (2007) mentioned that there are additional values to record keeping and genetic evaluation that a dollar value could not be accurately assigned. If a producer does not track additional metrics, the only advantage from parentage testing would be to remove bulls that are siring very few calves and those sires of dead calves as a result of a difficult birth.

Knowing which bull yielded the most $\mathrm{kg}$ of weaned calf is desirable, given that weaned calves are the primary income source for a cow-calf producer (Garrick and Golden 2009). Waiting until fall weaning means another breeding season has passed and the non-prolific bulls have been given another year to be unproductive or bulls that were causing dystocia have had another chance to breed females and create potential calving problems. Completing parentage testing of the entire calf crop prior to the start of the next breeding season may also not be possible. Instead, testing a smaller portion of the calves (those born in only week three of the calving season) has a greater chance of getting lab results to a producer in time (Van Eenennaam et al. 2014).

Knowing which bull's sired calves early in the breeding season is also valuable. The importance of getting females bred early (in first $21 \mathrm{~d}$ ) has long been known (Lesmeister et al. 1973) and once established, calving date changes very little (Burris and Priode 1958; Sprott 2000). If calving date is recorded, it can be paired with parentage results to identify top performing bulls. 


\subsection{Turnaround time from sampling to DNA parentage results}

Of the four cooperating herds in the study, only two operations provided DNA samples to the lab prior to weaning. It should be noted, that in yr two of the study all of the operations sent the DNA samples to the lab before weaning suggesting the producers found value in knowing parentage information before weaning.

The turnaround time from the lab ranged from 43 to $160 \mathrm{~d}$, averaging 98 days. The average commercial turnaround time for this lab is six to eight wk (Deobald 2015), however, a rush service is available. The cost of testing for the current study was covered by the lab as part of the business in-kind contribution to the project and therefore may have resulted in the longer turnaround times.

Besides lab turnaround times there was also human error in the sampling process that resulted in increased turnaround time. In some instances, DNA was not provided for all the potential sires or insufficient amounts of DNA were captured in the collection tag, which resulted in additional delays and/or the sire match not being found. When turnaround times exceed $21 \mathrm{~d}$, it is not possible for a cow-calf producer to parentage test all of the calf crop and receive results in a timely manner to allow for adjustments to the bull battery to be made before the start of the next breeding season.

\subsection{Costs of no sire match}

In each of the four operations there were calves that were found to have no sire match. Reasons for this included multiple matches (usually occurring when two or more bulls were closely related), DNA from all the potential sires was not provided, no tissue in the collection tag, or insufficient amounts of DNA in the collection tag. These are issues that producers should 
be aware of as there is a cost incurred but no benefit realized. Across the four ranches in the study, the percentage of calves with no sire match averaged $5 \%$, ranging from one to eight percent (Table 4.3). For a herd of 300 cows ( $95 \%$ calving rate), 5\% no sire match would mean 15 calves with no sire match at a testing cost of $\$ 175$ to $\$ 300$ per operation in lost testing costs.

\begin{tabular}{lccc}
\hline \multicolumn{4}{l}{ Table 4.3 Number and percent of calves with no sire match } \\
\hline Operation & Number of calves & No sire match & Percent (\%) \\
\hline Ranch A & 394 & 4 & 1 \\
Ranch B & 194 & 11 & 6 \\
Ranch C & 108 & 9 & 8 \\
Ranch D & 93 & 4 & 4 \\
\hline
\end{tabular}

In this study calves were not re sampled if 'no sire match' resulted due to insufficient tissue collected in the tag. To resolve no sire match calves the lab will re-test at no extra cost, but additional samples are often required. However, there is the added cost for the extra time and labour required to collect the extra samples, and the increased turnaround time. In this study, new additional calf samples were not sent so re testing did not occur. Dam DNA samples were also not provided if the calf was matched to multiple sires and the dam DNA was required to differentiate between the sires.

\subsection{Conclusions}

The cost to maintain a sire on an operation is borne by the cow herd, meaning that the bull cost per calf declines as the number of calves the bull sires increases. Using the assumptions 
of the economic model developed in this study producers are better off to use AI if bulls are siring less than 23 calves.

Lab costs for DNA parentage testing vary depending on the genetic laboratory that is used. Other costs associated with DNA parentage include time and labour to take samples, shipping costs, and costs associated with on farm data analysis. The producer's ability to interpret and incorporate the parentage data, the number of calves sired by each bull, and the timeline in which that data is received really determines how economically valuable the information obtained from DNA parentage testing is.

Since the current study only followed sires for one year no long term conclusions could be made based on the cost benefits of DNA parentage testing. Instead economic analysis focused on more short-term analysis. Using DNA parentage testing to increase total calf crop weaning weights by culling bulls siring calves with low weaning weight was evaluated. It was calculated that calves would have to gain an average of $2.61 \mathrm{~kg} / \mathrm{calf}$ for every $\mathrm{yr}$ DNA samples were collected and submitted to the lab. Therefore, DNA parentage testing should not be used solely for trying to increase total calf crop weaning weights.

DNA parentage testing also allows producers a method to remove non-prolific sires preventing them from incurring the cost to maintain a sire that is producing a low number of calves. The cull price of the bull, number of non-prolific sires, cost of parentage testing, number of calves sired, and cost to replace the bull all have an effect on whether DNA parentage testing to cull non-prolific sires will be beneficial for a producer.

Using DNA parentage testing to identify those bulls who are causing dystocia is most likely to be of economic value to a producer. By only testing the calves that were born from a 
difficult birth, producers are able to reduce the cost of testing. For a relatively low cost producers are able to determine if one bull is responsible for dystocia in their herd and if so cull the bull.

The true value in DNA parentage testing lies in the ability to combine all of the abovementioned benefits through the use of supporting production records and an individual animal identification system. By incorporating all of this information together, producers may be able to generate the most value from the parentage test.

The time from when samples were collected until results were returned to producers ranged from 43 to $160 \mathrm{~d}$, averaging 98 days. With the normal production cycle of a cow herd producers need to be able to receive results within $21 \mathrm{~d}$ to be able to analyze those results and make decisions on culling or buying new bulls.

The number of calves who could not be assigned to a sire was relatively low in the current study compared to previous studies. Still the cost of calves with no sire match ranged from $\$ 175$ to $\$ 300$, a cost to the producer with no economic return.

In conclusion, incorporating DNA parentage data may be of economic value to producers to improve overall herd weaning weights and conception rates, but it is only one tool and must be used in conjunction with other production records and management practices in order to be economically viable. 


\subsection{GENERAL DISCUSSION AND CONCLUSIONS}

A large variation in number of calves sired per bull in each breeding group was observed in the current study. Since every bull on a cattle operation is accumulating the same maintenance cost regardless of the number of calves sired, bulls who sire low numbers of calves are of low economic value, or may even be an economic loss to an operation.

Sire age was shown to play a role in bull fertility, and in the current study younger bulls were shown to sire on average a lower number of calves compared to mature bulls. It is interesting that there was greater variation in number of calves sired among mature bulls, suggesting that on average even though mature bulls do sire more calves, there are still low and high prolificacy bulls within the mature bulls in a breeding group.

By setting minimum benchmarks that must be achieved for bulls to pass the BSE is one method to accurately access bull fertility. In the current study all but 3 bulls passed the BSE before breeding, therefore no correlation was found between percent normal sperm or scrotal circumference and the calculated BPI or bull prolificacy, suggesting that the minimum threshold values set for the BSE are accurate at assessing bull fertility.

The bull:cow ratio along with number of bulls in a breeding group have also been shown to play a role in bull prolificacy. Although a low number of breeding groups were evaluated in this study there is a trend that suggests that more bulls in a pasture resulting in lower bull:cow ratios may result in more variation of calves sired.

Ultimately DNA parentage testing allows producers to retroactively asses bull libido and prolificacy. Although this is still beneficial there is limited use as the bull has to be breeding for at least one breeding season before the test can be done, and they may be out for two breeding seasons before producers are able to utilize the results. Therefore more research is needed into 
the factors that affect bull prolificacy. Ideally if producers could test for bull prolificacy before purchasing a bull they could save money in lost costs and maybe decrease the total number of bulls being used on their operation. If this were the case, the entire beef industry could move towards using bull prolificacy as a selection criteria.

If producers are already keeping basic production records for the cow herd there are a number of ways that DNA parentage testing may improve economic value of the operation. These include the ability to cull non-prolific sires before the bull accumulates more costs, or prevent further dystocia problems by testing calves that have had a difficult birth and culling the sire responsible. By keeping production records on the cow herd, producers can also better select replacement females that would increase specific traits (eg. weaning weight, ADG) in the herd by selecting only those sires that are actually passing these traits on to their female offspring.

The value that producers are able to gain from adopting DNA parentage testing will most likely depend on the level of record keeping and individual animal identification that is conducted. In some cases, such as preventing calf death loss due to dystocia or problem births, the cost of the test could be recovered through increased kgs of calf weaned, reduced death loss, higher rebreeding rates in cows and reduced labour cost to assist with difficult births. In cases where producers are trying to increase overall (total calf crop) $\mathrm{kg}$ weaned, DNA parentage testing is less likely to be of economic value.

In conclusion, there is a lot of variability in the number of calves sired by each bull within a cow-calf enterprise. And although the current study has identified certain factors that play a role in prolific sires, bull libido is complex and not one factor determines if a bull is high or low prolificacy. On farm DNA parentage testing has the potential to result in an economic 
return on investment, but parentage testing results and the decisions that can be made using this information only increases as the number and accuracy of production records increase. 


\subsection{REFERENCES}

Abo-Ismail, M.K., Vander Voort G., Squires J., Swanson K., Mandell I., Liao X., Stothard P., Moore S., Plastow G., and Miller S. 2014. Single nucleotide polymorphisms for feed efficiency and performance in crossbred beef cattle. BMC Genet. 15:14 1886.

Alberta Agriculture and forestry. 2008. The Beef Cow-Calf Manual. Alberta Agriculture and Food. Edmonton Alberta.

Almquist J.O., and Hale E.B. 1956. An approach to the measurement of sexual behavior and semen production of dairy bulls. Proc. $3^{\text {rd }}$ inter. Cong. Anim. Reprod. And A.I., Plenary Papers: 50 .

Amann R.P., Seidel G.E., and Mortime R.G. 2000. Fertilizing potential in vitro of semen from young beef bulls containing a high or low percentage of sperm with a proximal droplet. Theriogenol. 54:9 1499-515

Amer P.R., Nieuwhof G.J., Pollott G.E, Roughsedge T., Coningtn J., and Simm G. 2007. Industry benefits from recent genetic progress in sheep and beef populations. Anim. 1:10 1414-1426.

Anderson E.C., and Garza J.C. 2006. The power of single-nucleotide polymorphisms for large-scale parentage inference. Genetics. 172: 2567-2582.

Anderson D.E., and Rogers G.M. 2001. Prevention of lameness in cow-calf operations. Vet. Clin. N. Am-Food A 17:1 209-223.

Baggott D.G., and Russell A.M. 1981. Lameness in cattle. Br. Vet. J. 137:1 113-132.

Bagley C.V., and Burrell W.C. 1997. Understanding Bull Breeding Soundness Exams. Utah State University Extension Publications.

Barth, A.D., and Oko, R.J. 1989. Abnormal Morphology of Bovine Spermatozoa. Iowa State University Press, Ames, IA. pp. 130-192.

Barth, A. D. 1989. Influence of abnormal sperm morphology on conception rates in cattle. Proc. Soc. Theriogenol. 13: 39.

Barth, A. D., and Waldner, C. L. 1994. Factors affecting breeding soundness classification of beef bulls examined at the Western College of Veterinary Medicine. Can Vet J. 43: 274284.

Barth A.D. 2013. Bull Breeding Soundness Evaluation Manual., Third Edition. Western Canadian Association of Bovine Practitioners.

Beerwinkle L.G. 1974. Heat detection programs and techniques. NAAB $8^{\text {th }}$ Annu. Conf. on 
Beef AI. 24 pp.

Bellows R.A., Patterson D.J., Burfening P.J., and Phelps D.A. 1987. Occurrence of neonatal and potential mortality in range beef cattle II. Factors contributing to calf death. Theriogenol. 28:5 573-86.

Bellows R.A., Short E.E., and Richardson G.V. 1982. Effects of sire, age of dam, and gestation feed level on dystocia and postpartum reproduction. J. Anim. Sci. 55:1-18.

Blockey M.A. 1979a. Observations on group mating of bulls at pasture. Appl. Anim. Ethology. 5: $15-34$.

Blockey M.A. 1979b. Sexual behaviour of bulls at pasture: a Review. Theriogenol. 6:4 393-398.

Blockey M.A. 1976. Serving capacity - a measure of the serving efficiency of bulls during pasture mating. Theriogenol. 6:4 393-401.

Blockey M.A. 1981. Development of a serving capacity test for beef bulls. Applied Anim. ethology. 7; 307-319.

Bourdon R. M., and Brinks J. S. 1986. Scrotal circumference in yearling Hereford bulls: Adjustment factors, heritability's and genetic, environmental and phenotypic relationships with growth traits. J. Anim. Sci. 62: 4: 958-967.

Bongiorni, S., Mancini G., Chillemi G., Pariset L., and Valentini A. 2012. Identification of a short region on chromosome 6 affecting direct calving ease in Piedmontese cattle breed. PLoS ONE 7:12 e50137.

Brito L.F.C., Silva A.E.D. F., Rodrigues L.H., Vieira F.V., Deragon L.A.G., and Kastelic J. P. 2002. Effects of environmental factors, age and genotype on sperm production and semen quality in Bos indicus and Bos taurus AI bulls in Brazil. Anim. Reprod. Sci. 15 (70) 181-190.

Buchanan J., Woronuck G.N., Marquess L., Lang K., James S., Deobald H., Welly B.T., and Van Eenennaam A.L. 2016. Analysis of validated and population specific SNP parentage panels in pedigreed and commercial beef cattle populations. Can. J. Anim. Sci. $11: 39$.

Burris, M. J. and Priode, B. M. 1958. Effect of calving date on subsequent calving terformance. Amer. J. Ani. Sci. 17:33 527-533.

Campbell J. 2015. Personal communication. 17 February 2015.

Canfax Research Services. 2009. September 2009 Quarterly Report.

Canfax Research Services. 2015. Canfax Trends West 2012-2015. 
Canadian Angus Association. 2011. Member handbook. Available: http://www.cdnangus.ca/members/handbook/pdf/intro.pdf (accessed online August 8, 2014).

Carlberg J.G., and Hogan R.J. 2013. Can enhanced traceability generate extra value-added for cattle at auction? No 143043. 2013 Annual Meeting, Orlando, FL, Southern Agricultural Economics Association.

Carpenter B.B., Forrest D.W. Sprott S.R., Rocha A., Hawkins D.E., Beverly J.R., Hawkins H.E., and Parish N.R. 1992. Performance of Bos indicus-influenced bulls in serving capacity tests and multiple-sire breeding groups. J. Anim. Sci. 70:6 1795-1800.

Carroll E.J., Ball L., and Scott J.A. 1963. Breeding soundness in bulls - a summary of 10,904 examinations. J. Am. Vet. Med. Assoc. 1963:142 1005- 1111.

Carson R.L., and Wenzel J.G.W. 1997. Observations using the new bull-breeding soundness evaluation forms in adult and young bulls Vet. Clin. N. Am-Food A. 13:2 305-311

Chenoweth, P.J., and Osborne, H.G. 1975. Breed differences in reproductive function of young beef bulls in Central Queensland. Aust. Vet. J. 51: 405-406.

Chenoweth, P.J., Brinks, J.S., and Nett, T.M. 1979. A comparison of three methods of assessing sex-drive in yearling bulls and relationships with testosterone and LH levels. Theriogenol., 12:4 223-233.

Chenoweth, P.J., and Osborne, H.G. 1978. Breed differences in abnormalities of the reproductive organs of young beef bulls. Aust. Vet J. 54:10 463-468.

Chenoweth P.J. 1981. Libido and mating behaviour in bulls, boars and rams: A Review. Theriogeol. 16:2 155-177.

Chenoweth, P.J., Spitzer, J.C., and Hopkins, F.M. 1992. A new bull breeding soundness evaluation form. Proceedings of Annual Meeting, Society for Theriogenology San Antonio, TX. 63-71.

Chenoweth, P.J. 1997. Bull libido/serving capacity. Vet Clin N Am. Food A 13: 331-344.

Clark B.L., White M.B., Banfield J.C. 1971. Diagnosis of Trichomonas foetus infection in bulls. Aust. Vet. J. 47: 181-183.

Cobo E.R.,Favetto P.H., Lane V.M., Friend A., VanHooser K., Mitchell J., BonDurant R.H. 2007. Sensitivity and specificity of culture and PCR of smegma samples of bulls experimentally infected with Trichomonas foetus. Theriogenol 68 853-860

Coe P. H. 1999. Associations among age, scrotal circumference, and proportion of morphologically normal spermatozoa in young beef bulls during an initial breeding soundness examination. J. Am. Vet. Med. Assoc. 214:11 1664-1667. 
Collick D.W., Ward W.R., and Dobson H. 1989. Associations between types of lameness and fertility. Veterinary Record. 125:5 103.

Coulter, G. H. and Kozub, G. C. 1989. Efficacy of methods used to test fertility of beef bulls used for multiple-sire breeding under range conditions. J. Anim. Sci. 67:7 1757-1766.

Coulter G.H., and Foote R.H. 1979. Bovine testicular measurements as indicators of reproductive performance and their relationship to productive traits in cattle: a Review. Theriogenol. $11297-311$.

Crichton J.S., and Lishman A.W. 1988. Factors influencing sexual behavior of young Bos indicus bulls under pen and pasture mating conditions. Appl. Anim. Behav. Sci. 21: 281292.

Curi R.A., and Lopes C.R. 2002. Evaluation of nine microsatellite loci and misidentification paternity frequency in a population of Gyr breed bovines. Braz. J. Vet. Res. Anim. Sci. 39:3 129-135.

DeNise, S.K. 1999. Using parentage analysis in commercial beef operations. Page 183-190 in Proc. $31^{\text {st }}$ Ann. Res. Symp. Beef Improv. Fed., Roanoke, VA.

Dekkers J.M. 2004. Commercial application of marker- and gene-assisted selection in livestock: Strategies and lessons. J Anim Sci. 28:13 313-328.

Deobald, H. 2015. Personal communication. 24 April 2015.

Dziuk J.P. 1996. Factors that influence the proportion of offspring sired by a male following heterospermic insemination. Anim. Reprod. Sci., 43:2-3 65-88.

Ellis R.W., Rupp G.P., Chenoweth P.J., Cundiff L.V., and Lunstra D.D. 2005. Fertility of yearling beef bulls during mating. Theriogenol. 64: 3 657-678.

Elmore R.G., Bierschwal C.J., Martin C.E., and Youngquist R.S. 1975. A summary of 1127 breeding soundness examinations in beef bulls. Theriogenol. 3: 209-218.

Evans A.C.O., Pierson R.A., Garcia A., McDougall L.M., Hrudka F., and Rawlings N.C. 1996. Changes in circulating hormone concentrations, testes histology and testes ultrasonography during sexual maturation in beef bulls. Theriogenol. 46:2 345-357.

Farin, P.W., Chenoweth, P.J., Tomky, D.F., Ball, L., and Pexton, J. E. 1989. Breeding soundness, libido and performance of beef bulls mated to estrus synchronized females. Theriogenol. 32:5 717-725.

Farin P.W., Chenoweth P.J., Mateos E.R., and Pexton J.E. 1982. Beef bulls mated to estrus synchronized heifers: single-vs multi-sire breeding groups. Theriogenol. 17:4 365-372.

Fiaz M., Usmani R.H., Abdullah M., and Ahmad T. 2010. Evaluation of semen quality of 
Holstein Friesian and Jersey bulls maintained under subtropical environment. Pak. Vet. J., 30: $75-78$.

Fields M.J., Burns W.C., and Warnick A.C. 1979. Age, Season and Breed Effects on Testicular Volume and Semen Traits in Young Beef Bulls. J. Anim. Sci. 48:6 1299- 1304.

Foote R.H., Munkenbeck N., and Creene W.A. 1976. Testosterone and Libido in Holstein Bulls of various ages. J. dairy Sci. 59:11 2011-2013.

Fordyce G., Fitzpatrick L.A., Cooper N.J., Doogan V.J., De Faveri J., and Holroyd R.G. 2002. Bull selection and use in northern Australia. Anim. Reprod. Sci., 71: 81-99.

Galina C.S., Horn M.M., and Molina R. 2007. Reproductive behaviour in bulls raised under tropical and subtropical conditions. Horm. Behav. 52: 26-31.

Garmym, A.J., Moser, D.W., Christmas, R.A., and Minick-Bormann J. 2011. Estimation of genetic parmeters and effects on cytoplasmic line on scrotal circumference and semen quality traits in Angus bulls. J. Anim. Sci. 89: 693-698.

Garrick D.J., and Golden BL, 2009: Producing and using genetic evaluations in the United States beef industry of today. J. Anim. Sci. 87:14 11-18.

Godfrey, R.W., and Lunstra, D.D., 1989. Influence of single or multiple sires and serving capacity on mating behavior of beef bulls. J. Anim. Sci. 67, 2897-2903.

Hahn, J., Foote, R.H and Seidel G.E. 1969. Testicular growth and related sperm output in dairy bulls. J. Anim. Sci. 29:1 41-47.

Hamilton. 2006. Beef bull fertility. Ontario Ministry of Agriculture, Food and Rural Affairs Fact Sheet. Order No. 89-087.

Hammond J. 1927. The Physiology of reproduction in the cow. Cambridge University Press. London. 29-32.

Heaton, M. P., Harhay G.P., Bennett G.L., Stone R.T., Grosse W.M., Casas E., Keele J.W., Smith T.P., Chitko-McKown C.G., and Laegreid W.W. 2002. Selection and use of SNP markers for animal identification and paternity analysis in U.S. beef cattle. Mamm. Genome. 13:272-281.

Holroyd R.W., Doogan, V.J., De Faveri J., Fordyce G., McGowan M.R., Bertram J.D., Vankan D.M., Fitzpatrick L.A., Jayawardhana G.A., and Miller R.G. 2002. Bull selection and use in northern Australia. IV. Calf output and predictors of fertility of bulls in multiple-sire herds. Anim. Reprod. Sci., 71: 67-79.

Houghton P.L., Lemenager R.P., Horstman L.A., Hendrix K.S. and Moss G.E. 1990. Effects of body composition, pre- and postpartum Energy levels on reproductive performance of beef cows and pre-weaning calf gain. J. Anim. Sci. 68:5 1438-1446. 
Jelinski M., Campbell J., Hendrick S., and Waldner C. 2015. Survey of Saskatchewan beef producers regarding management practices and veterinary service usage. Can Vet J. 56:1 66-72.

Johnson K.R., Dewey C.E., Bobo J.K., Kelling C.L., and Lunstra D.D. 1998. Prevalence of morphologic defects in spermatozoa from beef bulls. J. AM. Vet. Assoc. 2013 1468-1471.

Johnson S.K. and Jones R. 2004. Costs and comparisons of estrous synchronization systems. Proc. Applied Reprod. Strateg. in Beef Cattle.

Kastelic J., and Thundathil J.C. 2008. Breeding Soundness Evaluation and Semen Analysis for Predicting Bull Fertility. Reprod. Domest. Anim. 43:2 368-373.

Kennedy S.P., Spitzer J.C., Hopkins F.M., Higdon H.L., and Bridges W.C. 2002. Breeding soundness evaluations of 3648 yearling beef bulls using the 1993 society for theriogenology guidelines. Theriogenol. 58: 947-961.

Kreplin 2007. Breeding Soundness Evaluation of Bulls. Alberta Agriculture and Forestry.

Kriese L.A., Bertrad J.K., and Benyshek L.L. 1991. Age adjustment factors, heritabilities and geneteic correlations for scrotal circumference and related growth traits in Hereford and Brangus bulls. 69:2 478-89.

Lardner, H.A., Larson, K. and Damiran, D. 2015. Comparison of fixed-time artificial insemination vs. natural service in beef cows: Reproductive efficiency and system cost. WBDC Fact Sheet \#2015-02.

Larson K. 2010. What is the cost of a herd sire? Western Beef Development Centre \#2010-04.

Larson K. 2013. 2012 Saskatchewan cow-calf cost of production analysis. Western Beef Development Centre. \#2013-02.

Larson, K. 2015. 2014. Western Canadian Cow-Calf Survey Aggregate Results. 34 pp.

Laster D.B., Glimp H.A., Cundiff A.V., and Gregory K.E. 1973. Factors affecting dystocia and the effects of dystocia on subsequent reproduction in beef cattle. J Anim. Sci. 36:4 695-705.

LeBlanc S. 2010. Assessing the association of the level of milk production with reproductive performance in dairy cows. J Reprod. Develop. 56: S1-S7.

Lesmeister J.L., Burfening P.J., and Blackwell R.L. 1973. Date of first calving in beef cows and subsequent calf production. J. Anim. Sci. 36:1 1-6.

Linford, E., Glover, F.A., Bishop, C. and Stewart, D.L. 1976. The relationship between semen evaluation methods and fertility in the bull. J. Reprod. Fertil. 47:283-291. 
Lopez H., Orihuela A., and Silva E. 1999. Effect of the presence of a dominant bull on performance of two age group bulls in libido tests. Appl. Anim. Behav. Sci. 65 13-20.

Lunstra, D.D. 1985. Effect of Single-Sire and Multiple-Sire Natural Mating on Pregnancy Rate of Beef Cattle. Roman L. Hruska U.S. Meat Animal Research Center. Paper 36.

Lunstra D.D., and Coulter G.H. 1997. Relationship between scrotal infrared temperature patterns and natural-mating fertility in beef bulls. J Anim. Sci. 75:3 767-774.

Lunstra D.D., and Echternkamp S.E. 1982. Puberty in Beef Bulls: Acrosome Morphology and Semen Quality in Bulls of Different Breeds. J Anim. Sci. 55:3 638-648

Martin, G.B., Tjondronegoro S., and Blackberry M. 1994. Effects of nutrition on testicular size and the concentrations of gonadotropins, testosterone and inhibin in plasma of mature male sheep. J Reprod Fert. 101:1 121-128.

McCosker T.H., Turner A.F., McCool C.J., Post T.B., Bell K. 1989. Brahman bull fertility in a north Australian rangeland herd. Theriog. 27 285-300.

Meijering A. 1984. Dystocia and stillbirth in cattle - a review of causes, relations and implications. Livestock Prod. Sci. 11 143-177.

Menon A., Barkema H., Wilde R., Kastelic J., and Thundathil J. 2011. Associations between sperm abnormalities, breed, age, and scrotal circumference in beef bulls. Can. J. Vet. Res. 75:4 241-247.

Meacham T., Cunha T., Warnick A., Hentges J., and Hargrove D. 1963. Influence of low protein rations on growth and semen characteristics of young beef bulls. J. Anim. Sci. 22:1 115-120.

Mwansa P.R., and Makarechian. 1991. The effect of post weaning level of dietary energy on sex drive and semen quality of young beef bulls. Theriogenol. 35:6 1169-1178.

National Academies of Sciences, Engineering, and Medicine. 2016. Nutrient Requirements of Beef Cattle: Eighth Revised Edition. Washington, DC: The National Academies Press.

Ologun A.G., Chenoweth P.J., and Brinks. J.S. 1981. Relationships among production traits and estimates of sex drive and dominance value in yearling beef bulls. Theriogenol. 15:4 379-388.

Parker S., Campbell J., Ribble C., Gajadhar A. 2003. Sample collection factors affect the sensitivity of the diagnostic test for Trichomonas foetus in bulls. Can. J. Vet. Res. 67: 138141.

Parkinson T.J, 2004. Evaluation of fertility and infertility in natural service bulls. Vet J. 168:3 215-29. 
Petherick J.C. 2005. A review of some factors affecting the expression of libido in beef cattle, and individual bull and herd fertility. App. Anim. Behav. Sci. 90:3-4 185-205.

Price E.O., and Wallach S.J.R., 1991. Effects of group size and the male-to female ratio on the sexual performance and aggressive behavior of bulls in serving capacity tests. J. Anim. Sci. 69:1034-1040.

Ramsay J.M., Hulsman H.L.L., and Ringwall K.A. 2016. Maximizing use of extension beef cattle benchmarks data derived from cow herd appraisal performance software. J. Extens. 54:3 3T0T5.

Rekwot P.I., Oyedipe E.O., Akerejola O.O., and Kumi-Diaka J. 1988. The effect of protein intake on body weight, scrotal circumference and semen production of Bunaji bulls and their Friesian crosses in Nigeria. Anim Reprodu Sci. 16:1 1-9.

Rekwot P.I., Oyedipe E.O., Akerejola O.O., Kumi-Diaka J., and Umoh J.E. 1987. The effect of protein intake in the onset of puberty in Bunji and Friesan x Bunaji Crossbred bulls in Nigeria. Theriogenol. 28:4 427-434.

Rowlands I.W., and Weir B.J., 1984. Mammals: non-primate eutherians. In: Lamming, G.E. (Ed.), Marshall's Physiology of Reproduction, vol. 1. Churchill Livingstone, Edinburgh. 455-658.

Rupp, G.P., Ball, L., Shoop, M.C., and Chenoweth, P.J., 1977. Reproductive efficiency of bulls in natural service: effects of male to female ratio and single- vs multiple-sire breeding groups. J. Am. Vet. Med. Assoc. 171: 639-642.

Ruttle J., Bartlett D., and Halford D. 1983. Fertility characteristics of New Mexico range bulls. New Mexico Agricultural Experiment Station Bull. No. 705.

Sagebiel J.A., Krause G.F., Sibbit B. Langford L. Comfort J.E., Dyer A.J., and Lasley J.F. 1969. Dystocia in reciprocally crossed Angus, Hereford and Charolais cattle. J anim Sci. 29:2 245-250.

Saunders P.J., and Ladds P.W. 1978. Congenital and developmental abnormalities of the genitalia of slaughtered bulls. Aust. Vet. J. 54:10-13.

Schein, M.W. and Fohrman, M.H., 1955. Social dominance relationships in a herd of dairy cattle. Br. J. Anim. Behav., 3:2 45-55.

Shelby C.E., Clark R.T., and Woodward R.R. 1955.The heritability of some economic characteristics of beef cattle. J Anim. Sci. 14:2 372-385.

Short R.E. and Adams D.C. 1988. Nutritional and hormonal interrelationships in beef cattle reproduction. Can. J. Anim. Sci. 68: 29-39. 
Sprott L.R. 2000. Reproductive Performance in Replacement Heifers has Long-Term Consequences on the Cow Herd. Texas A\&M Publication, ASWeb-100.

Sreenan J.M. and Diskin M.G. 1983. Early embryonic mortality in the cow: its relationship with progesterone concentration. Vet Rec. 112:22 517-521

St. Jean G., Gaughan E.M., and Constable P.D. 1992. Chryptorchidism in north American cattle: breed predisposition and clinical findings. Theriogenol. 38 951-958

Stalhammar, E.M., Janson L., and Philipsson J. 1989. Genetic studies on fertility in A.I. bulls. I. Age, Season and genetic effects on semen characteristics in young bulls. Anim. Reprod. Sci. 19:1-2 1-17.

Statistics Canada. 2012. Census of Agriculture 1956 to 2011. Available: http://www.statcan.gc.ca/pub/95-640-x/2012002/figs/figure17-eng.htm (Accessed May 15, 2014).

Strucken E.M., Lee S.H., Lee H.K., Song K.D., Gibson J.P., Gondro C. 2015. How many makers are enough? Factors influencing parentage testing in different livestock populations. J. Anim. Breed Genet. 10.1111

Tessitore E., Schwartzkopf-Genswein K.S., Cozzi G., Pajor E., Goldhawk C. Brown F. Janzen E., Klassen P., and Dueck C. 2011. Prevalence of lameness in 3 commercial feedlots in southern Alberta during summer months. Proc. Can. Soc. Anim. Sci. 75 pp.

Thundathil J., Palasz A.T., Barth A.D., and Mapletoft R.J. 2001. The use of in vitro fertilization techniques to investigate the fertilizing ability of bovine sperm with proximal cytoplasmic droplets. Anim. Repro. Sci. 65:3-4 181-192.

Unterschultz J. 2000. New instruments for Coordination and risk sharing within the Canadian beef industry. Project Report 00-04. Department of rural economy, Edmonton: University of Alberta, Edmonton, Canada.

Van Arendonk J., Hovenier R., and DeBoer W. 1989. Phenotypic and genetic association between fertility and production in dairy cows. Livest. Prod. Sci. 2: 11-12.

VanDemark N.L., Fritz G.R., and Mauger R.E. 1964. Effect of energy intake on reproductive performance of dairy bulls. I. Semen production and replenishment. J. Dairy Sci. $47: 898$.

Van Eenennaam A., and Drake D.J. 2012. Where in the beef cattle supply chain might DNA tests generate value? Live. Prod. Sci. 52:3 185-196.

Van Eenennaam A., Weber K.L., and Drake D.J. 2014. Evaluation of bull prolificacy on commercial beef cattle ranches using DNA paternity analysis. J. Anim. Sci. 92:6 26932701. 
Van Eenennaam A.L. Weber R.L., Drake D.J., Penedo M.C.T., Quaas R.L., Garrick D.J., and Pollak E.J. 2007. DNA-based Paternity Analysis and Genetic Evaluation in a Large, Commercial Cattle Ranch Setting. J. of Anim. Sci. 85 3159-3169.

Vignal, A., D. Milan, M. SanCristobal, and A. Eggen. 2002. A review on SNP and other types of molecular markers and their use in animal genetics. Genet. Sel. Evol. 34:3 275-305.

Waldner C.L., Kennedy R.I., and Palmer C.W. 2010. A description of the finding from bull breeding soundness evaluations and their association with pregnancy outcomes in a study of western Canadian beef herds. Theriogenol, 74: 871-883

Wagnon, K.A., Loy, R.G., Rollins, W.C. and Carroll, F.D., 1966. Social dominance in a herd of Angus, Hereford and Shorthorn cows. Anim. Behav. 14:4 474-479.

Wiggins G.R., Van Raden P.M., and Cooper T.A. 2011. The genomic evaluation system in the United States; Past, present, future. J. Dairy. Sci. 94:6 3202-3211.

Welsh T.H. and Johnson B.H. 1981. Stress-induced alterations in secretion of corticosteroids, progesterone, luteinizing hormone, and testosterone in bulls. Endocrinology 109:1 185190.

Wiltbank J.N. and Parish N.R. 1986. Pregnancy rate in cows and heifers bred to bulls selected for semen quality. Theriogenol. 25:6 779-783.

Zamboni L. 1992. Sperm structure and its relevance to infertility. Arch. Pathol. Lab Med. 116: 325-344. 


\subsection{APPENDICES}

Appendix A

Table A.1. Outline of cooperating ranches production stage

\begin{tabular}{|c|c|c|c|c|}
\hline & A & $\mathrm{B}$ & $\mathrm{D}$ & $\mathrm{F}$ \\
\hline \multicolumn{5}{|l|}{2014} \\
\hline BSE test & April & July & May & June \\
\hline Breeding & July 16 & Aug 1 & Jul 16 & May \\
\hline Pregnancy diagnosis & November & N/A & November & October \\
\hline \multicolumn{5}{|l|}{2015} \\
\hline Calving & April 25 & May 10 & Apr 25 & April \\
\hline BSE test & April & July & May & June \\
\hline Breeding & July & August & July & July \\
\hline Weaning & November & Dec-Mar & November & October \\
\hline Pregnancy diagnosis & November & N/A & November & October \\
\hline \multicolumn{5}{|l|}{2016} \\
\hline Calving & April & May & April & April \\
\hline BSE test & April & July & May & June \\
\hline Breeding & July & August & July & July \\
\hline Weaning & November & Dec-Mar & November & October \\
\hline Pregnancy diagnosis & November & $\mathrm{N} / \mathrm{A}$ & November & October \\
\hline
\end{tabular}


Appendix B

Table C.1. Assumptions used to calculate cost of maintaining herdsire

\begin{tabular}{|c|c|c|}
\hline & Value & Assumptions \\
\hline Days on Pasture & 185 & \\
\hline Days on Feed & 180 & Assume feeding November through April (6 months x 30 days) \\
\hline Total Days & 365 & \\
\hline Yardage & $\$ 1.17$ & $\begin{array}{l}\text { /WFD (winter feeding day); based on } 2012 \text { SK COP benchmarks } \\
\text { lb/day; } 2.5 \% \text { of body weight; Recommendation that } 2 \text { yr old bull }\end{array}$ \\
\hline Hay Amount & 35 & requires 30 to $35 \mathrm{lb}$ DM forage (p 145; The Beef Cow-Calf Manual) \\
\hline Hay (\$/tonne) & $\$ 92.49$ & $\begin{array}{l}\text { Source: Alberta Farm Input Prices Survey, } 2012-2015 \text { Average } \\
\text { /hd/day; Provide } 1.6 \text { ounces per day x } \$ 0.58 / \text { lb (Blair's Invoice); based }\end{array}$ \\
\hline Mineral/Salt & $\$ 0.10$ & on previous WBDC studies \\
\hline Pasture (\$/hd/day) & $\$ 1.00$ & $\begin{array}{l}\text { Source: AB } 2015 \text { Pastureland Lease and Rental Survey; SK } 2012 \\
\text { Private Pasture Rates }\end{array}$ \\
\hline $\begin{array}{l}\text { Barley (\$/tonne) } \\
\text { Barley (fed } \\
\text { amount) }\end{array}$ & $\$ 200.99$ & $\begin{array}{l}\text { Source: Alberta Farm Input Prices Survey, 2012-2015 Average } \\
\text { lb/day; Based on recommendation of } 5 \text { to } 7 \text { lb grain per day; The Beef } \\
\text { Cow-Calf Manual }\end{array}$ \\
\hline Barley (\# days fed) & 180 & days \\
\hline Bedding straw & $\$ 25.00$ & $\begin{array}{l}\text { /hd; Source: MB Cost of Production Tool; } 1 \text { ton } / \text { bull/year } \\
\text { based on WBDC costs to vaccinate for BVD, footrot, Blackleg and } \\
\text { parasite treatment }\end{array}$ \\
\hline Semen Test & $\$ 75.00$ & Source: Watrous Vet Clinic 2016 \\
\hline Purchase Price & $\$ 6,797.00$ & Source: Canadian Angus Association \\
\hline Cull Price $(\$ / 1 b)$ & $\$ 1.07$ & Source: Canfax; 2012-2015 average price for cull bulls \\
\hline Weight & 2000 & $\begin{array}{l}\text { lbs; estimate } \\
\text { Source: Johnson and Jones (2004); Stockton and Brooks (2015); }\end{array}$ \\
\hline Years of Use & 4 & WBDC is 3 years of use based 2007-2016 records \\
\hline Risk of Loss \% & 0.10 & Source: Johnson and Jones (2004); Stockton and Brooks (2015) \\
\hline \multicolumn{2}{|c|}{ \# of Cows Serviced/yr } & Source: Larson/WCCCS (2015); AARD (2008) \\
\hline
\end{tabular}

